NBER WORKING PAPER SERIES

THE SLIDE TO PROTECTIONISM IN THE GREAT DEPRESSION: WHO SUCCUMBED AND WHY?

\author{
Barry Eichengreen \\ Douglas A. Irwin \\ Working Paper 15142 \\ http://www.nber.org/papers/w15142
NATIONAL BUREAU OF ECONOMIC RESEARCH
1050 Massachusetts Avenue
Cambridge, MA 02138 \\ July 2009
}

For helpful comments we thank two referees, Ivan Berend, Forrest Capie, Steve Haber, Harold James, Kris Mitchener, Lars Jonung, Elias Papaioannou, John Singleton, Peter Temin, Gianni Toniolo, and Nikolaus Wolf and participants at the Dartmouth International Lunch. The views expressed herein are those of the author(s) and do not necessarily reflect the views of the National Bureau of Economic Research.

NBER working papers are circulated for discussion and comment purposes. They have not been peerreviewed or been subject to the review by the NBER Board of Directors that accompanies official NBER publications.

(C) 2009 by Barry Eichengreen and Douglas A. Irwin. All rights reserved. Short sections of text, not to exceed two paragraphs, may be quoted without explicit permission provided that full credit, including (c) notice, is given to the source. 
The Slide to Protectionism in the Great Depression: Who Succumbed and Why?

Barry Eichengreen and Douglas A. Irwin

NBER Working Paper No. 15142

July 2009, Revised February 2010

JEL No. F02,F13,F31,F42,N70

\begin{abstract}
$\underline{\text { ABSTRACT }}$
The Great Depression was marked by a severe outbreak of protectionist trade policies. But contrary to the presumption that all countries scrambled to raise trade barriers, there was substantial cross-country variation in the movement to protectionism. Specifically, countries that remained on the gold standard resorted to tariffs, import quotas, and exchange controls to a greater extent than countries that went off gold. Gold standard countries chose to maintain their fixed exchange rate and reduce spending on imports rather than allow their currency to depreciate. Trade protection in the 1930s was less an instance of special interest politics than second-best macroeconomic policy when monetary and fiscal policies were constrained.
\end{abstract}

\author{
Barry Eichengreen \\ Department of Economics \\ University of California, Berkeley \\ 549 Evans Hall 3880 \\ Berkeley, CA 94720-3880 \\ and NBER \\ eichengr@econ.Berkeley.edu \\ Douglas A. Irwin \\ Department of Economics \\ Dartmouth College \\ Hanover, NH 03755 \\ and NBER \\ douglas.irwin@dartmouth.edu
}




\section{The Slide to Protectionism in the Great Depression: Who Succumbed and Why?}

\section{Introduction}

The Great Depression of the 1930s was marked by a sharp outbreak of protectionist trade policies. Governments around the world imposed tariffs, import quotas, and exchange controls to restrict spending on foreign goods. These trade barriers contributed to a sharp contraction in world trade in the early 1930s beyond the economic collapse itself, and a lackluster rebound in trade later in the decade, despite the worldwide economic recovery. ${ }^{1}$

The rise in protectionism is well known, but most accounts of the period, whether gleaned from contemporary reports or subsequent histories, suggest that trade policy was thrown into chaos everywhere, with all countries scrambling equally to impose higher trade barriers. ${ }^{2}$ This was not exactly the case, as we show below. In fact there was considerable variation in the extent to which countries imposed protectionist measures. While some countries raised tariffs sharply and imposed draconian controls on foreign exchange transactions, others tightened trade and exchange restrictions only marginally.

What accounts for the cross-country variation in the use of protectionist measures? We argue the exchange rate regime and associated economic policies were key determinants of trade policies in the early 1930s. Countries that remained on the gold standard, keeping their currencies fixed, were more likely to restrict foreign trade. With other countries devaluing and

\footnotetext{
${ }^{1}$ See Madsen (2001).

2 See, for example, Kindleberger (1986, 1989) and James (2001).
} 
gaining competitiveness at their expense, they resorted to protectionist policies to strengthen the balance of payments and limit gold losses. Lacking other instruments, notably an independent monetary policy with which to address the deepening slump, they used trade restrictions to shift demand toward domestic goods and, they hoped, stem the rise in unemployment.

In contrast, countries that abandoned the gold standard, allowing their currencies to depreciate, saw their balances of payments strengthen. They gained gold rather than losing it. Abandoning the gold standard also freed up monetary policy. With no gold parity to defend, interest rates could be cut. No longer constrained by the gold standard, central banks had more freedom to act as lenders of last resort. Because they possessed other policy instruments with which to ameliorate the Depression, they were not forced to resort to trade protection as a second-best macroeconomic tool.

These findings are obviously related to the literature linking the gold standard to the Great Depression. ${ }^{3}$ This research associates the length and depth of a country's economic downturn and the timing and vigor of its recovery to how long it remained on gold. Countries abandoning the gold standard relatively early, such as Britain (which did so in September 1931), experienced relatively mild recessions and early recoveries. In contrast, countries remaining on the gold standard, such as France (which did not abandon gold convertibility until 1936), experienced prolonged slumps. Countries leaving the gold standard were able to relax monetary policy, whereas countries staying on gold were forced to maintain tight monetary policies that inhibited recovery.

We offer a trade-policy corollary to this thesis: countries remaining on the gold standard

3 See Choudhri and Kochin (1980), Eichengreen and Sachs (1985), Temin (1989), Campa (1990), Eichengreen (1992) and Bernanke (1995). 
$-4-$

and thereby prevented from using monetary stimulus to reflate were more inclined to tighten trade restrictions. The implication is that the stubbornness with which countries clung to the gold standard is part of the explanation for why the world trading system was felled by an outbreak of protectionism. Had countries been quicker to abandon gold standard orthodoxy and the restrictive monetary policies associated with it, it would have been easier to avert the restrictive commercial policies that destroyed the network of trade. Our account thus lends structure to what otherwise seems to be a haphazard scramble to close markets in the 1930s.

We start with a brief narrative of the deterioration of the trade policy environment. Next we examine the relationship between a country's exchange rate policy and three potential trade policy instruments: import tariffs, import quotas, and exchange controls. Although the available measures of the stance of trade policy in this period all have limitations, all of them are consistent with our thesis. We also account for the endogeneity of the choice to remain on or to go off the gold standard based on the basis of prior historical experience: on the monetary experience of countries in the early 1920s and on whether or not they had acquired the status of international financial center. Finally, we examine the evolution of trade costs to see if they are also consistent with our conclusions.

\section{The Gold Standard and the Great Depression}

The 1930s was not the first time the international monetary regime and trading system interacted with one another. But in the preceding period - from 1870 to 1913 - they interacted more positively. The classical gold standard linked many of the world's economies through a system of de facto pegged exchange rates. In addition to allowing the free movement of capital, 
$-5-$

the classical system facilitated the finance of trade and promoted its expansion. Lopez-Cordova and Meissner (2003) conclude that perhaps 20 percent of the growth in world trade between 1880 and 1910 was due to the stability provided by the fixed exchange rate regime.

Estevadeordal, Frantz, and Taylor (2003) reach similar conclusions and also show that trade barriers were relatively stable over this period.

This gold standard system was disrupted by World War I. All of the major belligerents except the United States placed barriers in the way of gold exports and loosened, in one way or another, the link between gold and the central bank currency and credit policies. After the war the gold standard was reconstructed as a gold-exchange standard, so called because it provided for expanded use of foreign exchange reserves (mainly sterling and dollars). Due to postwar economic and monetary dislocations the principal belligerents only resumed gold convertibility in the mid-to-late 1920s. Austria and Germany restored convertibility in 1923 and 1924 with the end of their hyperinflations. As other countries stabilized they too returned to the gold standard: Britain, Belgium, and the Netherlands in 1925, Canada, Czechoslovakia, and Chile in 1926, Denmark and Italy in 1927, France in $1928 .{ }^{4}$ While not all countries returned at their pre-war parities, the basics of the prewar international monetary system had been put back in place by the end of the decade.

As monetary stability was restored, commercial policies were liberalized. Although tariffs remained higher than before World War I because of the partial retention of wartime trade restrictions, the mid- and late-1920s saw a proliferation of bilateral trade agreements in which countries resurrected the most-favored nation (MFN) clause. The League of Nations then

\footnotetext{
${ }^{4}$ For a complete list of when various countries returned to the gold standard see Palyi (1970).
} 
convened a World Economic Conference in 1927 to prepare the ground for the coordinated relaxation of trade restrictions.

Unfortunately, the interwar gold-exchange standard was less robust than its prewar predecessor. Governments largely resurrected the prewar pattern of exchange rates despite the fact that relative financial strength and competitive positions had changed as a result of the war. Old gold parities were restored without lowering price levels to prewar levels, resulting in a lower ratio of the value of gold to nominal transactions. The remaining gold was unevenly distributed, with some 60 per cent in the hands of the United States and France.

While the resulting gold shortage was addressed by encouraging the more widespread use of foreign exchange reserves, this heightened the fragility of the system. The willingness of countries to hold foreign exchange was only as strong as the commitment of the reserve-center countries, the United States and Britain, to honor their commitments to convert their liabilities into gold at a fixed price. If those commitments were called into question, there might be a scramble out of foreign exchange, putting sharp deflationary pressure on the world economy And the credibility of those commitments was now less than before World War I. Whether central banks would subordinate other objectives to defending their gold parities was called into question by democratization, the rise of trade unions, and growing awareness of the problem of unemployment. If they wished to maintain investor confidence, central banks could not now show any inclination to deviate from the gold standard rules.

Finally, the international cooperation that had helped to support the prewar system, allowing countries in crisis to continue to adhere to gold parities, was more difficult in the aftermath of a war that had bequeathed ill will, war debts, and reparations. 
-7-

For all these reasons, the interwar gold standard was incapable of withstanding the shock of the Great Depression. ${ }^{5}$ The system immediately came under strain with the economic slowdown and recession that began in 1928-29. The trigger for this downturn continues to be debated, although recent accounts have highlighted the decision by the Federal Reserve Board to tighten monetary policy and the French decisions to de jure stabilize the franc at a depreciated rate and to convert holdings of foreign exchange reserves into gold, all in 1928 (Hamilton 1987, Eichengreen 1992, Johnson 1997). These policies drained gold from the rest of the world and required other countries to pursue more restrictive monetary policies.

Options for responding were limited. Unilateral changes in monetary policy - significant ones at least - were precluded by the gold standard. Expansionary fiscal policy was ruled out by the orthodoxy that governments should run balanced budgets even in downturns. ${ }^{6}$ This left three options: enduring a grinding wage and price deflation to restore external and internal balance at the current gold parity; imposing trade and payments restrictions to limit spending on imports and reduce gold outflows; or abandoning the gold standard and allowing the exchange rate to depreciate.

Some countries remained on the gold standard in the hope that, with sufficient wage and price deflation, they could restore internal and external balance. But the difficulties of wage deflation were considerable, and the burden of long-term debts denominated in nominal terms

\footnotetext{
${ }^{5}$ Chernyshoff, Jacks, and Taylor (2009) find that, the reconstructed gold standard after whereas the classical gold standard allowed countries to absorb terms of trade shocks well, World War I did not.

${ }^{6}$ For example, the British Treasury held the view that fiscal policy would be ineffective in dealing with the slump; see Peden (1990). This view was shared by most policymakers around the world, although Japan, Sweden, and Germany were exceptions in their willingness to use deficits to finance spending on public works.
} 
$-8-$

became progressively heavier. Rising unemployment also had political costs; more than a few governments fell as a result. Some therefore banned capital outflows and imposed direct controls on payments for imports to conserve gold and foreign exchange reserves. In effect they preserved the façade of the gold standard (their de jure exchange rates did not change) but without the reality (freedom to import and export gold and the statutory link between foreign reserves and money supplies were abrogated or, at best, honored in the breach).

Still other countries chose or were forced to abandon gold convertibility and permit their currencies to depreciate. By severing the link between the monetary base and gold reserves, they were able to pursue more expansionary monetary policies.

Insofar as the problem was too little gold, the first-best policy response would have been a worldwide reduction in gold reserve ratios, essentially a monetary expansion achieved through international policy coordination. ${ }^{7}$ In effect, this is what had happened by 1936 but without the international coordination. One country after another abandoned the gold standard and allowed its gold reserve ratio to fall (equivalently, one country after another raised the domestic-currency price of gold). Although the prior constellation of bilateral exchange rate was largely restored at the end of the process, the constraints on monetary policy had been relaxed relative to the counterfactual in which the original gold standard rules remained in place.

But the haphazard manner in which this result came about had enormous implications. The unilateral way in which one group of countries left the gold standard created difficulties for the others. Given their reluctance to follow, it put pressure on them to limit gold exports by

\footnotetext{
${ }^{7}$ There could have been agreement to cut interest rates in concert and to reduce gold cover ratios. But such agreement was impossible to reach given different countries' different histories (which rendered them more or less willing to contemplate modification of their gold-standard statutes) and their different diagnoses of the nature of the problem (Eichengreen and Uzan 1992).
} 
$-9-$

raising interest rates, restricting imports, or regulating foreign exchange transactions. In essence, the difficulties facing the international monetary system created spillover problems for commercial policy.

\section{The Trade Policy Reaction}

The movement toward more restrictive trade policies first became evident immediately following the 1929 business cycle peak. The United States imposed the Smoot-Hawley tariff in June 1930, raising the average tariff on dutiable imports by about 20 percent. ${ }^{8}$ The increase in American tariffs was resented abroad, particularly as the United States was an international creditor and exports to the U.S. market were already declining. Smoot-Hawley provoked retaliatory responses, notably from the country’s largest trading partner, Canada, as well as from a handful of European countries. ${ }^{9}$ Yet, while Smoot-Hawley clearly gave other countries an excuse to raise trade barriers, it was not the main trigger for the wave of protectionist measures beginning in 1931. In comparison to what was to come, relatively few countries actually raised their tariffs in late 1930 and early $1931 .^{10}$

\footnotetext{
${ }^{8}$ Despite this timing, the Smoot-Hawley tariff was not a direct response to the Depression because the basic structure of the tariff rates was set by the House Ways and Means Committee in early 1929, well before the business cycle peak. Although Senate consideration of the bill continued through early 1930, few rates were significantly changed, making it difficult to view the tariff act as an anti-depression measure. Subsequent deflation increased the ad valorem equivalent of the many specific duties in the tariff code to much higher levels, but this would have occurred even in the absence of the legislation; see Crucini (1994) and Irwin (1998).

${ }^{9}$ Jones (1934) provides a detailed analysis of the foreign reaction against the Smoot-Hawley tariff. MacDonald, O’Brien, and Callahan (1997) focus on Canada’s response.

${ }^{10}$ Indeed, the impact of Smoot-Hawley was more limited than is sometimes suggested. The legislation increased the average tariff on dutiable imports from 40 to 47 percent, increasing the domestic relative price of imports by just six percent. Without doubt, the higher duties discouraged the importation of manufactured goods from Europe, but only six percent of
} 
$-10-$

The spark that caused the world trading system to collapse was the financial crisis in the summer of 1931. ${ }^{11}$ The failure of the largest Austrian bank, the Creditanstalt, unsettled financial markets and caused capital flows to seize up. The German government depended on foreign loans to finance its expenditures, and the drying up of those loans triggered a run on the mark and a loss of gold reserves (Ferguson and Temin 2003, Temin 2008). The government was forced to impose strict controls on foreign exchange transactions. In theory Germany could have devalued, but the reparations agreement fixed its obligation in dollars of constant gold content. This meant that devaluing would have had devastating effects on the public finances. In any case memories of hyperinflation when the gold standard was in abeyance meant that abandoning the system would have unleashed a collective hysteria. ${ }^{12}$ To limit losses of gold and foreign exchange reserves, Germany therefore imposed controls on capital movements as well as trade finance. Hungary was hit, since its financial system was tied to Austria’s; it imposed controls in July 1931. Other countries such as Chile, which was battered by declining copper prices, followed with controls of their own.

Europe's exports were destined to the United States in 1928. Furthermore, the tariff did not significantly affect developing countries in Latin America since most of the raw materials that they exported entered the U.S. market duty free. Still, the tariff was ill-advised; it could do little to relieve the problems faced by the U.S. agricultural sector, which was the ostensible purpose of the legislation. And it was poorly timed; it helped undermine the negotiation of a tariff truce in Europe.

${ }^{11}$ While acknowledging the role of the Smoot-Hawley tariff in poisoning international trade relations, the League of Nations $(1942,52)$ wrote that "a new and far more critical phase in the development of restrictions on trade opened with the financial crises in Austria and Germany in the early summer of 1931.”

12 As James (1986, 390) writes, “There were widespread fears that a devaluation would lead to an uncontrollable slide of the Mark. These may have been the consequence of the recent and painful memories of the inflation and hyperinflation . . . . It was quite realistic to believe that German abandonment of the gold standard would destroy the only precariously restored financial stability of Germany.” See also Straumann (2009). 
$-11-$

In August the pressure spread to Britain as trade credits extended to Germany by British merchant banks were frozen. ${ }^{13}$ A sharp increase in interest rates did little to stem the Bank of England's gold losses. Against the backdrop of rising unemployment which rendered the Bank reluctant to raise interest rates further, the need for lender-of-last-resort intervention now tipped the balance. On September 19, Britain abandoned the gold standard and allowed sterling to depreciate.

That depreciation sent shockwaves through the world economy. Other countries either followed Britain off gold or imposed restrictions on trade and payments as a defensive measure to reduce imports and strengthen the balance of payments. Within days, other countries with close trade and financial ties to Britain -- Denmark, Finland, Norway, and Sweden among them - allowed their currencies to depreciate relative to gold. Japan, concluding that its recent resumption of gold convertibility had been a mistake, followed in December.

Other countries responded by imposing exchange controls to stem gold outflows. In September-October 1931 exchange controls were adopted by Uruguay, Colombia, Greece, Czechoslovakia, Iceland, Bolivia, Yugoslavia, Austria, Argentina, Belgium, Norway, and Denmark (Gordon 1941, 54-55). In addition, the improvement in the price competitiveness of exports from countries with depreciated currencies prompted defensive countermeasures in countries remaining on the gold standard. Within months, a large number of countries ratcheted up their tariffs to block cheap imports. France imposed a 15 percent surcharge on British goods to offset the depreciation of sterling and adopted more restrictive import quotas. Canada and

\footnotetext{
${ }^{13}$ Many trade credits extended to Germany in the 1920s had been provided by British merchant banks, which is why the German standstill spilled over disproportionately to Britain. In some cases the expected losses on the frozen German credits exceeded the capital of the merchant banks in question (Accomminotti 2009).
} 
$-12-$

South Africa, two countries that did not delink from gold along with Britain, adopted

antidumping duties aimed at imports from Britain. In January 1932 the German government was

empowered to raise "equalizing" tariffs on goods coming from countries with depreciated

currencies. The Netherlands also broke from its traditional policy of free trade, raising its duties

by 25 percent to offset currency depreciation abroad.

This chaotic scramble to protect domestic markets and safeguard the balance of payments

is aptly described by League of Nations (1932, 289):

"It is impossible in any brief summary to make anything like a complete statement of all the various devices brought into use to restrict trade. Especially after the abandonment of the gold standard by Great Britain in September 1931, there has been a veritable panic, which has piled new tariffs on old, turned licensing systems into prohibitions, monopolies and contingents; denounced existing commercial agreements; created more and more rigid exchange controls issuing in debt moratoria and paralysing trade; and substituted a slight and temporary framework of clearing agreements for previous existing treaties ... .There has never before been such a wholesale and widespread retreat from international economic co-operation.”

A year later, League of Nations (1933, 16-17) again recounted the dramatic events set in motion

following Britain’s decision to abandon gold:

"The multiplicity and variety of these emergency restrictions [on international trade] after September 1931 is difficult to summarise in a few words ... In the sixteen months after September $1^{\text {st }}$, 1931, general tariff increases had been imposed in twenty-three countries, in three of them twice during the period - with only one case of a general tariff reduction. Customs duties had been increased on individual items or groups of commodities by fifty countries, in most cases by a succession of enactments which, in several countries, numbers over twenty tariff changes in the sixteen months. Import quotas, prohibitions, licensing systems and similar quantitative restrictions, with even more frequent changes in several important cases, had been imposed by thirty-two countries. Import monopolies, for the most part of grains, were in existence in twelve countries; milling or mixing regulations in sixteen others. Export premiums were being paid in nine, while export duties or prohibitions had been imposed in seventeen. This bare list is utterly inadequate to portray the harassing complexity of the emergency restrictions that were superimposed upon an already fettered world trade after the period of exchange instability was inaugurated by the abandonment of the gold standard by the United Kingdom in September 1931. By the middle of 1932, it was obvious that the 
$-13-$

international trading mechanism was in real danger of being smashed as completely as the international monetary system had been." ${ }^{4}$

This proliferation of restrictions on international trade and payments in the aftermath of Britain's devaluation dealt a severe blow to world commerce. The volume of world trade fell 16 percent from the third quarter of 1931 - just prior to these events - to the third quarter of 1932 (League of Nations 1939a, 62). As Figure 1 shows, it fell 25 percent between 1929 and 1932, with much of the deterioration coming in 1932. According to Madsen (2001), somewhat less than half of this overall reduction was due to higher tariff and non-tariff barriers. ${ }^{15}$

There are several reasons why Britain's abandonment of gold, coming on the heels of the financial crisis in Central Europe, triggered this protectionist avalanche. First, it quickly became not just a British devaluation but a wholesale devaluation. If Britain, a leading gold standard country, acknowledged that there were more important policy objectives than pegging the domestic price of gold, others could now show less hesitation about recognizing this fact (the “nobody-told-us-we-could-do-that” phenomenon). As many as twenty other countries

\footnotetext{
${ }^{14}$ Similarly, the Bank for International Settlements $(1933,12)$ noted: “The multiplication of tariffs, quotas, and prohibitions in recent years has largely been a result of sudden currency changes: There can be very little hope of a return to freer trade so long as the present monetary uncertainty prevails."

${ }^{15}$ Estevadeordal, Frantz, and Taylor (2003) conclude that the collapse of the gold standard, higher transportation costs, and tariffs all contributed to the higher trade costs and hence the contraction of trade-to-GDP ratios in the 1930s. It is also possible that this global round of tariffs could have had modest macroeconomic effects. One analysis of them using a mainstream neoclassical model is Eichengreen (1989), which considers the impact of tariffs in an economy with sticky wages on which is superimposed a deflationary shock. To the extent that the shock causes debt deflation resulting in unemployment, a tariff neutralizes some of the effects by raising prices. This is true even when both countries in this two-country model respond to the common shock with tariff hikes. But tariffs also have other effects that work in the direction of further depressing output, rendering the net effect unclear. What is clear is other policies targeted directly at the disturbance are significantly more effective in raising output. See also Eichengreen (1981) and Foreman-Peck, Hughes-Hallett, and Ma (2007).
} 
$-14-$

abandoned gold following the Bank of England's announcement. ${ }^{16}$ Currency depreciation by countries accounting for upwards of a quarter of global GDP ratcheted up the pressure on the others to do something.

Second, Britain's action led to the widespread liquidation of not just sterling but also dollar reserves, forcing the Federal Reserve to raise interest rates to stem gold losses. Higher U.S. interest rates put upward pressure on rates in other gold standard countries. Once again there was pressure to do something. Some gold-standard countries imposed exchange controls to limit trade and capital flows. Others simply imposed higher tariffs to discourage imports.

Third, Britain itself followed the depreciation of sterling with higher tariffs. In November 1931 it enacted an Abnormal Importation Duties Act which gave the authorities discretion to impose higher duties on selected goods. In February 1932, Parliament passed the Import Duties Act imposing a 10 percent across-the-board tariff on imports, with additional restrictions on certain imports and exemptions for imports from the Empire. This made life still more difficult for other countries that depended on the British market. Those not benefiting from Imperial preferences responded with higher tariffs of their own.

Our hypothesis of course suggests that Britain should have been less inclined to resort to protectionism once it gained the ability to loosen monetary policy. ${ }^{17}$ Why then did it go ahead

\footnotetext{
${ }^{16}$ The countries included not just those mentioned, but Japan, Portugal, Greece, Finland, Estonia, Latvia, Bolivia, Egypt, India, Thailand, Iran, and Iraq.

${ }^{17}$ Having abandoned the gold standard the authorities could cut interest rates. Unlike other countries, Britain now had better ways of supporting demand than using a tariff to re-route spending toward domestic goods. Consistent with this, prior to September 1931 John Maynard Keynes had argued for a tariff on the grounds that it was the only available means of supporting domestic demand, monetary policy being immobilized by the gold standard and fiscal policy by the Treasury view that a fiscal expansion would be ineffective. Once the gold standard was abandoned, he rejected protection as redundant. Moggridge $(1992,514)$ notes: "By refusing
} 
$-15-$

with the tariff? The natural answer is politics (Capie 1983, Williamson 1992, Garside 1998).

The Conservative Party had long advocated protectionism and had already moved the country in that direction in the early 1920s; it now gained power in the National Government formed at the height of the crisis. ${ }^{18}$ Parliament was dissolved on October $7^{\text {th }}$, and the subsequent election resulted in an increase in Conservative influence in the Cabinet and House of Commons. Neville Chamberlain, son of the Conservative arch-protectionist Joseph Chamberlain, became Chancellor of the Exchequer in the new government. The Labour Party, which had supported free trade and been in power during the crisis, was discredited, leaving a protectionist Conservative Party to drive policy by default.

Another factor was the weakness of the balance of payments. The tariff was not adopted to support employment, a problem that was addressed by the depreciation. The goal, rather, was to strengthen the balance of payments, given fears of large scale withdrawals of foreign balances. Britain had been home to large deposits and investments by foreign central banks and private investors. While these might not be withdrawn en masse, their steady liquidation might put dangerous downward pressure on the currency, precipitating its collapse, or so it was feared. The tariff was designed to strengthen other components of the balance of payments in order to head off this eventuality (Eichengreen 1990).

Central to this story is the reaction of countries that remained on the gold standard despite

openly to advocate devaluation and by lending his public support for protection ... Keynes helped create a climate of opinion in which, after Britain left gold and did not need protection on Keynes's grounds, she got a highly protective tariff system anyway.”

18 Thus, the Conservatives had been behind the Tariff Reform movement in the decades leading up to World War I and had succeeded in pushing through a limited tariff, the Safeguarding of Industries Act, in 1921, which imposed a 33 per cent ad valorem tariff on the products of nine industries built up during the war and added anti-dumping provisions. See Hirst (1925). 
$-16-$

the turmoil of 1931. As we have seen, one set of countries that remained on the gold standard was the exchange control group, led by Germany, which restricted foreign currency transactions. The other group, the so-called gold bloc countries, led by France but including Belgium, the Netherlands, and Switzerland, persisted with deflationary policies. They raised tariffs and tightened quotas on imports in an effort to insulate their economies from the downturn and protect their gold reserves. However, they avoided the use of exchange controls and continued to allow international capital mobility.

Thus, in the midst of the global depression, countries that remained on the gold standard sought to improve their balance of payments position and preserve their gold and foreign exchange reserves. This could be achieved either by limiting capital exports through exchange controls (Germany) or by limiting spending on imports through trade restrictions (France), or both. In fact, such policies were substitute for one another. If exchange controls were comprehensive, they could be administered in a manner that left no need for additional measures such as tariffs or quotas. Import licensing and government allocation of foreign exchange meant that officials could determine the total amount of spending on imports and allocate that spending across different goods and country suppliers. Therefore, a country imposing exchange controls might not have to resort to higher tariffs and quotas because it already had the ability to limit imports through administrative action.

A number of countries defy easy categorization, as their policy response reflected not just the exchange rate regime but also special circumstances. Denmark, for example, was a member of the sterling bloc and as such had close trade and financial ties to Britain. But as an agricultural exporter it suffered unusually extensive discrimination against its exports because 
$-17-$

many tariffs and quotas in the 1930s were directed at agricultural goods. It experienced an especially adverse terms-of-trade shock, which severely affected its ability to import. Unlike other sterling bloc countries, therefore, Denmark imposed exchange controls. ${ }^{19}$

Table 1 summarizes the stance of the four different country groupings, along with the timing of their actions. Most sterling-bloc countries went off the gold standard in late 1931. The gold bloc countries in column two remained on the gold standard until September 1936, except for Belgium which went off gold in March 1935. Most exchange control countries applied their foreign exchange restrictions in mid- to late-1931. The last column lists a final group of countries that never joined or left the gold standard at various other points, including Spain (never on the gold standard), Canada (formally delinked from gold in January 1929 but maintained a peg to the dollar), and the United States (delinked in April 1933).

\section{Evidence from Trade Policy Measures}

This section examines the evidence that currency devaluation and trade and exchange controls were substitutes and that countries leaving the gold standard did not impose protectionist measures to the extent as countries remaining on gold.

\footnotetext{
${ }^{19}$ By the end of 1931, 95 per cent of the value of Danish imports required foreign exchange permits. Evidence presented below suggests that, despite its devaluation along with Britain in 1931, Denmark should be categorized as an exchange control country. As Salmon (2003, 234) notes, "For Denmark, the depression inaugurated acute problems of adjustment and brought farreaching institutional changes .... . Its response was to introduce a system of exchange and import control which transformed Denmark almost overnight from one of the most liberal economies in Europe to one in which there was 'a greater regulation of economic life than in any other western country with the possible exception of Germany.' The key instrument was the import licensing system introduced in the autumn of 1931.” Also see Thomsen and Thomas (1966) and Johansen (1987). An extended discussion of additional country cases can be found in the working paper version of this article (available at www.nber.org).
} 


\section{A. Tariffs}

The simplest indicator of the level of tariff protection is customs revenue as a share of the value of imports. This measure is sometimes criticized as downward biased because high or prohibitive duties get low or no weight. That said, average tariffs have been shown to be highly correlated with better measures of trade policy. ${ }^{20}$

Figure 2 presents the average tariff for selected countries in 1928, 1935, and $1938 .^{21}$ As predicted, the sharpest increases between 1928 and 1935 are concentrated among members of the gold bloc and exchange control countries. With the exception of Britain, the sterling-bloc countries show only relatively minor increases in average tariff rates between 1928 and 1938. . By contrast, the average tariff of every member of the gold bloc rose noticeably between 1928 and 1935. Among exchange control countries, the average tariffs of Austria, Germany, and Italy escalated significantly while those of Czechoslovakia and Hungary did not. As noted above, this last fact can be explained by the fact that administrative controls on foreign exchange are

${ }^{20}$ Kee, Nicita, and Olarreaga (2008) find that the correlation coefficient between the average tariff and a more accurate measure of trade policy - the trade restrictiveness index of Anderson and Neary (2005) - is 0.75 for a recent sample of countries. Similarly, Rodríguez and Rodrik (2001, 316) conclude, "It is common to assert . . that simple trade-weighted tariff averages or non-tariff coverage ratios - which we believe to be the most direct indicators of trade restrictions - are misleading as indicators of the stance of trade policy. ... [yet] an examination of simple averages of taxes on imports and exports and NTB coverage ratios leaves us with the impression that these measures in fact do a decent job of rank-ordering countries according to the restrictiveness of their trade regimes.” Another criticism of this measure is that it fails to capture the structure of protection, either the effective rate of protection (the relative importance of tariffs on intermediate and final goods) or differences in rates of protection afforded sectors and industries producing different final goods. For this paper, where we are concerned with the macroeconomics of protection, we would argue that such considerations are second order. All this suggests that the average tariff can a useful indicator of trade policy if used with care. ${ }^{21}$ These are based on data on customs revenue and imports presented in Mitchell (2007). Some of them were also used by Clemens and Williamson (2004), who kindly shared their data with us. 
effectively a substitute for tariffs.

Next we more systematically examine changes in the average tariff between 1928 and 1935 in a cross section of countries; 1928 is just before the business cycle peak for most countries, while 1935 is roughly when trade protectionism peaked. A shorter period like 192832 would not pick up the determinants of that decision as effectively since a number of the countries that suffered chronic deflation and unemployment as a result of opting to stay on the gold standard had only begun to experience such difficulties and had not yet ratcheted up tariffs. Similarly, a longer period like 1928-38 would be less informative in that most countries had gone off the gold standard by 1938, limiting the variation in the key independent variable, and insofar as some of the earlier gold standard countries that protected their markets previously scaled back those measures subsequently. ${ }^{22}$

Figure 3 is a scatter plot of the change in the average tariff and change in gold parity between 1928 and $1935 .^{23}$ The change in the tariff is expressed as $\Delta \log (1+\tau)$, where $\tau$ is the average tariff rate. The change in the gold parity indexes ounces of gold per unit of domestic currency in 1935 relative to $1928(1928=100)$. We present one panel for a core group of mainly European countries $(n=21)$ and another for the full sample that includes many developing countries $(n=40) .{ }^{24}$ Both samples indicate that countries abandoning the gold standard and depreciating their currencies were less likely to raise tariffs.

There is considerable variation around the average relationship. In some instances these

\footnotetext{
${ }^{22}$ We show evidence to this effect below.

${ }^{23}$ The format mimics the scatter plots linking industrial production and its correlates with the exchange rate regime in Eichengreen and Sachs (1985).

24 The larger sample disguises much of the variation in the response of the core countries on which the bulk of the historical literature focuses.
} 
deviations reflected idiosyncratic national circumstances, e.g. whether a country had lacked tariff autonomy in the 1920s and therefore sought to make up lost ground when it was restored in the 1930s, as was the case for Turkey and Egypt. In others, like the British case discussed above, they reflect the particulars of national politics. In still other instances deviations from the average relationship reflect the magnitude of the shock and other dimensions of the policy response, as analyzed below.

Despite this variation, regression analysis confirms the existence of a systematic relationship between the change in the average tariff and the change in the exchange rate. We estimate a regression of the form:

(1) $\Delta \log$ TARIFF $_{i}=a+b_{1} \Delta$ PARITY $_{i}+b_{2}$ EXCHCONTROL $_{i}+b_{3} \Delta \log$ WPI $_{i}+e_{i}$

where TARIFF is defined as $\left[\left(1+\tau_{1935}\right) /\left(1+\tau_{1928}\right)\right]$, which is the change in (one plus) the tariff rate between 1928 and 1935 for country $\mathrm{i}$, and $\Delta$ PARITY $_{\mathrm{i}}$ is the gold parity in 1935 relative to 1928, defined as the amount of gold that can be purchased with a unit of domestic currency, EXCHCONTROL is an indicator variable for whether a country imposed exchange controls, and WPI is the wholesale price index $(1929=100)$. The exchange control indicator is included since countries with controls in place did not have to resort to higher tariffs in order to switch demand toward domestic goods. Including the price level helps control for the effect of deflation on the ad valorem equivalent of specific duties.

The first three columns of Table 2 present OLS estimates adding the exchange control indicator and log of wholesale prices sequentially. In each case, the coefficient on the exchange 
rate in 1935 (relative to the 1929 parity) is positive and significantly related to the change in tariffs between 1928 and 1935. This confirms the relationship in Figure 5: countries maintaining their gold parities tended to increase their tariffs more than others.

This parsimonious specification may suffer from omitted variable bias in that there are other determinants of the change in tariffs that we cannot measure. We therefore checked the robustness of the result with respect to the inclusion of additional controls such as a country's trade-to-GDP ratio in 1928 and political regime. ${ }^{25}$ These tended to be insignificant, and none of them noticeably affected the results.

Simultaneity bias (if the decisions to devalue and change tariffs were driven by the same factors) and reverse causality (if countries with a differential willingness to abandon free trade therefore had a differential willingness to stay on the gold standard) could also contaminate the results. ${ }^{26}$ The standard treatment for these problems is instrumental variables. A source of plausible instruments in this case is prior historical experience. Eichengreen and Sachs (1985) argue that the decision to maintain the gold standard was heavily shaped by the country’s monetary experience in the aftermath of World War I. ${ }^{27}$ Countries experiencing high inflation (Belgium, Bulgaria, Czechoslovakia, and France) or hyperinflation (Austria, Germany, Hungary, Poland) in the early 1920s hesitated to abandon the gold standard in the 1930s for fear of reigniting inflation and rekindling disruptive distributional conflicts. They saw it as necessary to

\footnotetext{
${ }^{25}$ From the Polity database; http://www.systemicpeace.org/polity/polity4.htm

${ }^{26}$ Several recent papers have dealt with the endogeneity of the decision to go off the gold standard in the 1930s (Wolf and Yousef 2007, Wandschneider 2008, Wolf 2008).

${ }^{27}$ By contrast, Bernanke (1995) argues that economic conditions in 1930 were very similar across countries, and yet some chose to leave the gold standard in 1931 and others did not; his argument is that cross-country differences in economic performance (whether caused by trade policy or anything else) were not the driving factor in the decision to abandon gold.
} 
prevent a recurrence of high inflation and financial self-destruction. Other countries that had not shared this searing experience, such as the Scandinavians, were also more willing to abandon gold in response to the downturn. This suggests using a measure of cumulative inflation (the price level in 1925 where $1913=100$ ) as an instrument for the exchange rate and possibly in addition for the decision to impose exchange controls. ${ }^{28}$

Another source of plausible instruments is financial-center status. Countries that were host to international financial centers (Britain, France, the Netherlands, Switzerland, and the United States) were reluctant to leave the gold standard because they feared losing financial business to other countries. Although Britain did leave the gold standard under duress, other countries with financial-center status were reluctant to abandon the gold standard even in response to the exigencies of the Depression. ${ }^{29}$ This suggests using a binary indicator variable for financial center status as a second instrument. ${ }^{30}$

These variables satisfy the exogeneity requirement for valid instruments insofar as both the financial center indicator and cumulated inflation are predetermined (they are determined by past history and not contemporaneous changes in tariff policy). Financial center status is acquired over time; it is largely a function of events occurring prior to the 1930s. Inflation in the

${ }^{28}$ Alternatively we included high- and hyperinflation dummies; again the results remain essentially unchanged. We also tried a weighted regression, using the log of real GDP from Maddison (2006) as weights, but this had virtually no effect on the results.

${ }^{29}$ The potential loss of financial center status gave even Keynes pause in advocating that Britain abandon the gold standard. Why Britain's status as a financial center did not suffice to keep her on the gold standard is an interesting question and the subject of a literature of its own (Williamson 1992). One answer is that Britain was the only financial center to suffer a financial crisis, which left it little choice but to abandon gold. Wandschneider (2008) shows that banking crises significantly reduced the probability of countries staying on the gold standard.

${ }^{30}$ Whether Paris deserves this financial-center status is somewhat debatable; see Myers (1936). The coefficient estimates reported below remain basically unchanged when it is excluded, although significance levels are slightly lower. 
1920s was obviously exogenous to changes in the exchange rate in the 1930s. As for the

relevance criterion for a valid instrument, these variables are also likely to be correlated with the decision to abandon the gold standard for the reasons given. ${ }^{31}$

The last three columns of Table 2 report the results. When the change in parity is instrumented using the dummy variable for financial center status, the coefficient is both larger

${ }^{31}$ One might plausibly think that countries with authoritarian political regimes would be more likely to resort to exchange controls; restrictions on political freedom and economic freedom tended to go together in this as in other periods. A country's political regime in 1929 could then be used as an instrument for the exchange control indicator (our earlier robustness analysis, recall, suggesting that this variable can be excluded from the second stage). In fact, this instrument works nearly as well as the log of the early 1920s price level. The other variables considered by Wolf and Yousef (2007), Wandschneider (2008), Wolf (2008) are not as useful for our purposes in that they are not plausibly exogenous with respect to exchange rate policy. Wolf (2008) finds that banking crises, central bank independence, gold reserves, the character of the political system, and the identity of one's most important trading partner all had an impact on the timing of a country's exit from the gold standard. But few if any of these variables are useful for our purposes, since they are unlikely to satisfy the exclusion and exogeneity restrictions for a valid instrument. The change in gold reserves was one of the factors motivating the adoption of tariffs on balance of payments grounds; that is, it was likely to affect the decision to intensify protection directly. Banking crises causing some countries to depreciate their currencies may cause others raise their tariffs. Wandschneider (2008) similarly discusses the determinants of the exchange rate decision but provides few useful instruments for our investigation. As variables increasing the likelihood of staying on the gold standard she identifies per capita income, bilateral trade arrangements, the incidence of banking crises, the depth of the Depression, and the political regime, all of which are likely to affect trade policy directly and/or be affected by it. Wolf and Yousef (2007) consider many of these same variables and in addition peer or network effects, as in Simmons (1994) and Gallarotti (1995) in the form of how many other countries were on the gold standard in a given year. The idea is that the more of one's peers also adhere to the gold standard, the more attractive this remains for an individual country. It is not obvious the same peer pressure relevant for the decision to stay on the gold standard is relevant to the decision to maintain or abandon free trade. Mechanically, the number of other countries still on gold would not be the same as the number of other countries resisting higher tariffs.

Economically, the peers that are relevant for the trade policy decision are countries one trades with; the peers relevant to the gold standard decision may be countries for which one competes for funds, or number of countries showing by their actions that gold convertibility is still associated with monetary policy and fiscal prudence. Still, with the number of countries on going down steadily over time, this variable may be picking up not just peer effects but also other influences that move with time. 
than its OLS counterpart and more precisely estimated. However, the first-stage F statistic suggests that the instrument may be weak. In the second column we include a dummy variable for exchange control countries, which is also endogenous since countries using exchange controls had problems achieving monetary stability after World War I and therefore wanted to remain on the gold standard. As an instrument we use our measure of cumulated inflation. The results show the same pattern as in column 1, namely a point estimate on the change in exchange rate parity that is larger than the OLS coefficient. ${ }^{32}$ The first-stage F statistics are now larger and give less concern about weak instruments. Column 3 includes the log of the wholesale price in 1935 (relative to 1929) as an additional covariate. The pattern is the same as in column 2: depreciated currencies were associated with smaller tariff increases.

Thus, the results confirm the existence of a relationship between the change in the exchange rate and the change in import tariffs between 1929 and 1935 . The IV estimates imply that the observed association between the two is not driven by omitted variables or reverse causation.

We also ran these regressions for 1928-1932 and 1928-1938. Earlier we presented arguments for why the results for these alternative periods should be weaker. As expected, the results for 1932 are uninformative, reflecting the fact that in many countries important changes in trade policy had only begun taking place. The results for 1938 are similar to those for 1935 . $^{33}$

\footnotetext{
${ }^{32}$ In the IV regression, exchange control is treated as an endogenous dummy variable, so it would be inappropriate to estimate the first stage through non-linear methods such as probit. Hence, the first stage is simply a linear OLS regression of exchange control on the two instruments. Alternatively, we used peak annual inflation in the 1920s as the first-stage measure of inflation. Again the basic results carry over (both point estimates and quasi t-statistics change only slightly).

${ }^{33}$ They are somewhat weaker than the results in Table 3, as expected. In particular, only when
} 


\section{$\underline{\text { Import Quotas }}$}

Systematic data on import quotas in this period do not, to our knowledge, exist.

However, the League of Nations calculated the share of imports covered by quotas for eight countries in 1937. In Figure 4, we present its figures along with the exchange rate in $1935 .{ }^{34}$ As the figure shows, sterling bloc countries (Sweden, United Kingdom, Norway, Ireland) employed import quotas to a much lesser extent than gold bloc countries (Belgium, France, Netherlands, Switzerland). The implication is that countries with depreciated currencies did not resort to import quotas to the same extent as countries remaining on gold. ${ }^{35}$ While the sample is admittedly small, a t-test rejects the hypothesis of no difference in the use of quotas across the two groups at the 98 per cent confidence level. Of course, countries with exchange controls had other administrative mechanisms for allocating foreign exchange and did not need to impose quotas. They were not included in the League's tabulations.

\section{B. Exchange Controls}

Table 1 lists the major countries that imposed exchange controls. ${ }^{36}$ As noted earlier, Germany and central European countries were the main users of the policy. They implemented them not simply to prevent the loss of gold and foreign exchange reserves but as a new and

one controls for exchange control is it obvious that exchange rate choice matters for tariff policy. ${ }^{34}$ The date of the exchange rate is before the 1936 devaluation of the gold bloc currencies; although some liberalization in these quantitative restrictions had taken place, the quotas tended to persist for some period after the change in exchange rates.

${ }^{35}$ As with most aggregate measures of non-tariff barriers, there are no details on how binding these import quotas were. In the United States, the coverage of import quota coverage was small and largely reflects a single commodity (sugar). Again, this is consistent with our hypothesis, the United States having depreciated the dollar in early 1933.

${ }^{36}$ The list is not complete; many Latin American countries imposed exchange controls, but they do not have enough other data to be used in our other empirical analysis. See Obstfeld and Taylor (1998) for a discussion of exchange controls in this period. 
permanent part of their trade and payments regime. In other words, controls were used to limit spending on imports. Members of the sterling bloc and other countries depreciating their currencies are not widely represented on the list; to the extent that these countries every employed exchange controls, they were used only briefly during periods of financial crisis, not as an instrument of commercial policy to reduce spending on imports (except for Denmark). Gold bloc countries that remained on the gold standard foreswore the use of exchange controls and maintained international capital mobility throughout this period.

In the absence of estimates of the relative restrictiveness of exchange controls, it is hard to estimate their effects. ${ }^{37}$ But one can indirectly assess their effects by looking at the change in the volume of imports across countries. In effect we are required to look at the impact of the choice of exchange rate regime on trade policy outputs (the volume of imports) rather than trade policy inputs (tariffs and quotas).

Normally one would expect countries depreciating their exchange rates to curtail their imports relative to countries maintaining their currencies at prevailing levels, other things equal. But Figure 5, which presents the change in import volume between 1928 and 1935, shows the opposite: import volumes fell much more for gold bloc and exchange control countries that remained on the gold standard. This is consistent with the conclusion that countries maintaining their currencies at prevailing levels imposed restrictive trade measures that depreciating countries did not.

Of course, changes in the volume of trade are closely related to changes in domestic

${ }^{37}$ Insofar as clearing arrangements were often associated with such measures, they provide an indirect indicator: by 1937, 12 percent of world trade was conducted through clearing arrangements, including more than half of the trade of Bulgaria, Germany, Greece, Turkey, Romania, Hungary, and Yugoslavia (League of Nations 1942, 70). 
economic activity. Hence deviations from this relationship may be more informative about the potential impact of trade and payments restrictions. Figure 6 illustrates the relationship between changes in import volume and changes in real GDP between 1929 and 1935, controlling for whether a country imposed exchange controls. The underlying regression is:

$$
\Delta \log (\text { import volume })=-0.11+1.04 \Delta \log (\text { real GDP })-0.26 \text { EXCHCONTROL }
$$

where EXCHCONTROL is a dummy variable for exchange control countries $\left(n=21, R^{2}=0.69\right.$; robust standard errors in parentheses). ${ }^{38}$ As the figure and regression indicate, countries imposing exchange controls reduced their imports by about 23 percent more (exp[-0.26]-1), on average, than one would have expected based on the change in GDP. Most of the observations well below the regression line - such as Argentina, Chile, Denmark, Germany, Hungary, Italy were exchange control countries. This suggests that such controls were a significant factor in reducing international trade. ${ }^{39}$

To conclude, the broad pattern across trade policy instruments - tariffs, import quotas, and exchange controls - suggests that abandoning the gold standard and depreciating one's currency was a substitute for the use of trade policies to restrict spending on imports. While none of the measures of commercial policy is ideal, the pattern across them is consistent.

\section{Trade Costs}

While there is no single summary measure of the stance of trade policy, recent research

\footnotetext{
${ }^{38}$ Data on the change in import volume is from the League of Nations (1939a). Real GDP is from Maddison (2006).

39 This finding is consistent with more recent evidence in Wei and Zhang (2007) that exchange controls have a very adverse effect on trade.
} 
$-28-$

(e.g. Anderson and van Wincoop 2004) has developed an encompassing metric of the costs of international trade known as “trade costs.” This measure refers to any and all impediments to the exchange of goods across countries, not just government trade barriers but other costs of exchange, such as language barriers and distance, shipping and transportation costs, information and distributional costs, financing costs and uncertainty, and so forth. While trade costs as so measured have tended to decline over time, the early 1930s was unusual in that they rose sharply, as documented by Jacks, Meissner, and Novy (2009a, 2009b). ${ }^{40}$ They show that rising trade costs can account for most of the reduction in trade between 1921 and 1939, and it is plausible that a significant fraction of the variation at this time was policy induced.

Following these authors, trade costs can be calculated using trade and GDP data for country pairs to fit an equation of the form:

(2) $\quad \tau_{j, k}=1-\left(\frac{E X P_{j, k} E X P_{k, j}}{s_{j}\left(G D P_{J}-E X P_{J}\right) s_{k}\left(G D P_{k}-E X P_{k}\right)}\right)^{\frac{1}{2 \rho-2}}$ where $\tau_{\mathrm{j}, \mathrm{k}}$ is the country-pair specific costs of trade between country $\mathrm{j}$ and $\mathrm{k}$ (it is the geometric average of the bilateral trade barriers even if the trade barriers are asymmetric), $\mathrm{EXP}_{\mathrm{j}, \mathrm{k}}$ is real exports from $\mathrm{j}$ to $\mathrm{k}, \mathrm{GDP}_{\mathrm{j}}$ is the real output of country $\mathrm{j}$, and $\mathrm{EXP}_{\mathrm{j}}=\sum_{\mathrm{k} \neq \mathrm{j}} \mathrm{EXP}_{\mathrm{j}, \mathrm{k}}$. The elasticity of substitution is $\rho$ and $s_{j}$ is the share of tradable goods production in country j. Following Jacks, Meissner, and Novy, we set $\rho=8$ and $s=0.8$. We draw data on bilateral trade flows in 1928, 1935 and 1938 from League of Nations’ Network of World Trade (1942). ${ }^{41}$

\footnotetext{
${ }^{40}$ Hynes, Jacks, and O’Rourke (2009) similarly examine how higher trade costs led to the disintegration of world commodity markets in the early 1930s.

41 The nominal value of exports is converted to 1990 dollars using the U.S. consumer price index, following Jacks, Meissner, and Novy. We use Maddison's data for real GDP (1990 dollars). We are grateful to Jacks, Meissner and Novy for sharing their panel data on bilateral trade with us; unfortunately, their sample of countries under-represents the exchange control group and hence we decided to use the more complete League of Nations data. A shortcoming
} 
$-29-$

Figure 7 presents a scatter plot of the change in a country's trade costs and in its exchange rate from 1928 to 1935 . The correlation is positive and thus consistent with the thrust of our argument. While the correlation in question is relatively weak $(r=0.17)$, this may reflect the fact that other factors and not just commercial policies can affect trade costs. ${ }^{42}$ Indeed, a precise interpretation of trade costs is difficult; trade costs for a bilateral pair is the geometric mean of their respective costs, making it difficult to determine exactly which country factors are responsible for the change. In other words, if one country liberalizes its policy while another restricts trade, trade costs between them may not change even though the policies pursued in each are quite different. Just as data on trade policy barriers are imperfect, the trade cost figures are also imperfect.

With this caveat in mind, trade costs can be explored further by looking at trade costs by groups of trade partners for selected countries. Table 3 presents trade costs for the leading members of the sterling bloc, the gold bloc, and the exchange control group, namely, Britain, France, and Germany respectively, by type of trade partner. The first column indicates ad valorem trade costs in 1928, the second the percentage increase in trade costs by 1935 . Overall trade costs for Britain in 1928 were equivalent to a 63 percent ad valorem tariff; they then rose by some 8 per cent by $1935 .^{43}$ The corresponding increase was greater for the gold bloc than the

of the League's data is that 1932, when trade barriers and trade costs were probably at their peak, is omitted from their tabulations.

${ }^{42}$ For example, a country that allowed its currency to depreciate might not have imposed trade restrictions that would have increased trade costs, but its ending the gold standard would generated uncertainty about future exchange rates and raised trade costs (Jacks, Meissner, and Novy 2009b).

${ }^{43}$ While the differential costs in 1928 are of some interest (Britain's trade costs with exchange control countries was higher in 1928 than with the sterling bloc, as distance, colonial ties, and a host of other factors would lead one to expect), we are more interested in the change across 
$-30-$

sterling bloc, as expected, but lower for the exchange control group (which is not something that would necessarily have been expected on the basis of commercial policy measures alone). France’s trade costs rose nearly 10 percent between 1928 and 1935; its trade costs with the sterling bloc were lower than with the gold bloc and exchange control group, which would have been expected given the trade policy measures employed by both groups. ${ }^{44}$ Germany's overall trade costs rose nearly 12 percent, as one would have expected given the impact of exchange controls on trade. (The increase in trade costs was lower with other exchange control countries presumably due to bilateral clearing arrangements.)

Two findings are relevant to our hypothesis. First, Germany's trade costs rose more than those of Britain or France between 1929 and $1935 .{ }^{45}$ Second, costs of trade with gold bloc countries rose more than costs of trade with any other European group. Both of these findings are consistent with the theme of this paper. While the differentials are not large, small differences in trade costs could have a big impact on trade flows; most estimates of the elasticity of trade with respect to trade costs find that it is about 7 .

In sum, changes in trade costs as conventionally measured are fully consistent with our hypothesis.

groups in the 1930s. Jacks, Meissner, and Novy (2009b) find that trade costs fell between 1932 and 1935. Thus, the rise in trade costs between 1928 and 1935 is less dramatic than between 1928 and 1932.

${ }^{44}$ Again, interpretation here is complicated by the fact that trade costs between two gold bloc countries would remain lower because both were on the gold standard but would also increase because these countries had a greater propensity to impose import quotas on trade. ${ }^{45}$ The peak impact of exchange controls was in the early to mid-1930s; by 1938, Germany's trade costs had fallen considerably. Furthermore, to the extent that trade costs reflect policy developments, there is evidence that Germany discriminated in favor of exchange control countries and against others. 


\section{Trade Liberalization after Exiting Gold}

If countries remaining on the gold standard raised trade barriers as a result of their inability to resort to other more conventional policies to stabilize their economies and financial systems, it follows that countries should have begun relaxing their trade restrictions once they abandoned gold. There is evidence of this. In 1934, a year after the United States went off gold, Congress enacted the Reciprocal Trade Agreements Act authorizing the president to reduce U.S. import duties in trade agreements with other countries. Within four years, the agreements reached under the act had essentially undone the Smoot-Hawley tariff increase (Irwin 1998).

Similarly, once the remaining gold bloc countries devalued in September 1936 and started recovering from the slump, they began removing some of their trade barriers. League of Nations $(1942,85)$ noted that "Before the end of October 1936, tariff reductions and/or quota relaxations had been announced in France, Switzerland, the Netherlands, Italy, Czechoslovakia, and Latvia.” For example, having devalued in September, France reduced its tariffs by 15-20 per cent the next month, and Switzerland reduced many of its import tariffs by more than 50 per cent. $^{46}$ Relaxing the gold constraint and pursuing more expansionary monetary policies relieved the pressure to maintain restrictive trade policies. On the other hand, countries imposing exchange controls never formally abandoned the gold standard and consequently continued to restrict trade through such controls for the rest of the decade.

\footnotetext{
46 The League of Nations’ World Economic Surveys for 1936/37 and 1937/38 speak of a “net movement” toward liberalization. Madsen (2001) finds that the small degree of trade liberalization after 1936 contributed to the growth of world trade during that time.
} 


\section{Conclusions}

With the outbreak of the Great Depression, policy makers were confronted with an economic policy dilemma. In the face of an unprecedented macroeconomic collapse, the available choices were deflation under the gold standard, currency depreciation, or direct controls over trade and payments to maintain gold and foreign exchange reserves. Most countries rejected deflation as too wrenching given the severity of the shock and the magnitude of the requisite wage and price adjustment. Hence, these three options were effectively reduced to two: maintaining fixed exchange rates or maintaining open trade. ${ }^{47}$

We find evidence of this policy tradeoff: countries that stayed on the gold standard tended to impose tighter trade restrictions than those that allowed their currencies to depreciate. Having sacrificed one policy instrument (monetary autonomy) that might potentially have been used to counter the Depression, policy makers in their desperation resorted to another (trade controls). Historical circumstances conditioned this choice. Countries that had suffered high inflation after World War I chose to stay on the gold standard and maintain the exchange rate peg; effectively, they sacrificed trade policy on the altar of financial stability. The same was true of countries that had acquired financial-center status and now valued its maintenance. France and other countries in this position used import tariffs and quotas to regulate trade and the balance of payments; Germany and the exchange control countries did not maintain free capital mobility, leaving only the choice of whether to impose higher tariffs or allocate foreign exchange

\footnotetext{
${ }^{47}$ This choice set is somewhat analogous to the interwar trilemma between capital mobility, fixed exchange rates, and monetary autonomy analyzed by Obstfeld, Shambaugh, and Taylor (2004). The policy dilemma considered in this paper was examined by James Meade (1955), who concluded that "free trade and fixed exchange rates are incompatible in the modern world." His own preference was for depreciation over trade controls on the grounds that the latter had a number of unfortunate corollary costs.
} 
to regulate trade and the balance of payments. Countries that did not suffer from monetary problems after World War I or had no financial-center status to defend went off the gold standard, allowed their currency to depreciate, and were able to maintain more liberal trade policies.

Our account helps explain why some countries were more inclined than others to a protectionist response and lends structure to the otherwise chaotic tale of the collapse of world trade. It suggests that had more countries been willing to abandon the gold standard and use monetary policy to counter the slump, fewer would have been driven to impose trade restrictions in the desperate if ultimately futile effort to stem the rise in unemployment. 


\section{References}

Accomminotti, Olivier. 2009. “Contagion and the Sterling Crisis of 1931.” Unpublished manuscript: UC Berkeley and Sciences-Po (March).

Anderson, James, and Eric van Wincoop. 2004. “Trade Costs.” Journal of Economic Literature 42, 691-751.

Anderson, James, and J. Peter Neary. 2005. Measuring the Restrictiveness of International Trade Policy. Cambridge: MIT Press.

Bank for International Settlements. 1936. Annual Report. Basel: BIS.

Bernanke, Ben. 1995. “The Macroeconomics of the Great Depression: A Comparative Approach.” Journal of Money, Credit and Banking 27, 1-28.

Bordo, Michael D., and Angela Redish. 1990. “Credible Commitment and Exchange Rate Stability: Canada’s Interwar Experience.” Canadian Journal of Economics 23, 357-380.

Campa, Jose M. 1990. "Exchange Rates and Economic Recovery in the 1930s: An Extension to Latin America.” Journal of Economic History 50, 677-82.

Capie, Forrest. 1983. Depression and Protectionism: Britain between the Wars. London: George Allen \& Unwin.

Chernyshoff, Natalia, David S. Jacks, and Alan M. Taylor. 2009. “Stuck on Gold: Real Exchange Rate Volatility and the Rise and Fall of the Gold standard, 1875-1939.” Journal of International Economics 77, 195-205.

Choudhri, Ehsan, and Levis Kochin. 1980. “The Exchange Rate and the International Transmission of Business Cycle Disturbances: Some Evidence from the Great Depression.” Journal of Money, Credit, and Banking 12, 565-74.

Clemens, Michael A. and Jeffrey G. Williamson. 2004. "Why Did the Tariff-Growth Correlation Change after 1950?” Journal of Economic Growth 9, 5-46.

Crucini, Mario. 1994. "Sources of Variation in Real Tariff Rates: the United States, 1900-1940.” American Economic Review 84, 732-743.

Eichengreen, Barry. 1981. "A Dynamic Model of Tariffs, Output and Employment under Flexible Exchange Rates.” Journal of International Economics 11, 341-359.

Eichengreen, Barry. 1989. “The Political Economy of the Smoot-Hawley Tariff.” Research in Economic History 12, 1-43. 
Eichengreen, Barry. 1990. “Sterling and the Tariff, 1929-31.” In Elusive Stability: Essays in the History of International Finance, 1991-1939. New York: Cambridge University Press.

Eichengreen, Barry. 1992. Golden Fetters: The Gold Standard and the Great Depression, 19191939. New York: Oxford University Press.

Eichengreen, Barry and Marc Flandreau. 2008. “The Rise and Fall of the Dollar, or When did the Dollar Replace Sterling as the Leading International Currency?” NBER Working Paper No. 14154 (July).

Eichengreen, Barry, and Douglas A. Irwin. 1995. "Trade Blocs, Currency Blocs, and the Reorientation of World Trade in the 1930s.” Journal of International Economics 38, 1-24.

Eichengreen, Barry, and Jeffrey Sachs. 1985. "Exchange Rates and Economic Recovery in the 1930s.” Journal of Economic History 45, 925-46.

Eichengreen, Barry and Marc Uzan (1992), “The 1933 World Economic Conference as an Instance of Failed International Cooperation,” in Peter Evans, Harold Jacobson and Robert Putnam (eds), Double-Edged Diplomacy: International Bargaining and Domestic Politics, Berkeley: University of California Press, pp.171-206.

Estevadeordal, Antoni, Brian Frantz, and Alan M. Taylor. 2003. "The Rise and Fall of World Trade, 1870-1939.” Quarterly Journal of Economics 118, 359-407.

Ferguson, Thomas, and Peter Temin. 2003. "Made in Germany: The German Currency Crisis of 1931.” Research in Economic History 21: 1-53.

Foreman-Peck, James, Andrew Hughes-Hallett, and Yue Ma. 2007. “Trade Wars and the Slump.” European Review of Economic History 11, 73-98.

Gallarotti, Guilio. 1995. The Anatomy of an International Monetary Regime: The Classical Gold Standard. New York: Oxford University Press.

Garside, W. R. 1998. "Party Politics, Political Economy and British Protectionism, 1919-1932.” History 83, 47-65.

Gordon, Margaret. 1941. Barriers to World Trade. New York: Macmillan.

Haber, Stephen, Armando Razo and Noel Maurer. 2004. The Politics of Property Rights: Political Instability, Credible Commitments, and Economic Growth in Mexico, 1876-1929.

Cambridge: Cambridge University Press.

Hamilton, James. 1987. “Monetary Factors in the Great Depression.” Journal of Monetary 
Economics 19, 145-169.

Hirst, F.W. 1925. From Adam Smith to Philip Snowden: A History of Free Trade in Great Britain. London: T. Fisher Unwin.

Irwin, Douglas A. 1998. "Changes in U.S. Tariffs: The Role of Import Prices and Commercial Policies,” American Economic Review 88, 1015-1026.

Jacks, David S., Christopher M. Meissner, and Dennis Novy. 2008. “Trade Costs, 1870-2000.” American Economic Review 98, 529-534.

Jacks, David S., Christopher M. Meissner, and Dennis Novy. 2009a. "Trade Costs in the First Wave of Globalization.” Explorations in Economic History, forthcoming.

Jacks, David S., Christopher M. Meissner, and Dennis Novy. 2009b. "Trade Booms, Trade Busts, and Trade Costs.” NBER Working Paper No. 15267.

James, Harold. 1986. The German Slump: Politics and Economics, 1924-1936. Oxford: Clarendon Press.

James, Harold. 2001. The End of Globalization. Cambridge: Harvard University Press.

Johansen, Hans Christian. 1987. The Danish Economy in the Twentieth Century, London: Croom Helm.

Johnson, H. Clark. 1997. Gold, France, and the Great Depression. New Haven: Yale University Press.

Kee, Hiau L., Alessandro Nicita, and Marcelo Olarreaga. 2008. "Import Demand Elasticities and Trade Distortions.” Review of Economics and Statistics, 90, 666-682.

Kindleberger, Charles P. 1986. The World in Depression, 1929-1939. Revised edition. Berkeley: University of California Press.

Kindleberger, Charles P. 1989. "Commercial Policy between the Wars.” In Peter Mathias and Sidney Pollard (eds), The Cambridge Economic History of Europe, Volume 8: The Industrial Economies: The Development of Economic and Social Policies. New York: Cambridge University Press.

League of Nations. 1932. World Economic Survey 1931/32. Geneva: League of Nations.

League of Nations. 1933. World Economic Survey 1932/33. Geneva: League of Nations.

League of Nations. 1938. Report on Exchange Controls. Geneva: League of Nations. 
League of Nations. 1939a. Review of World Trade 1938. Geneva: League of Nations.

League of Nations. 1939b. World Economic Survey 1938/39. Geneva: League of Nations.

League of Nations. 1939c. World Production and Prices 1938/39. Geneva: League of Nations.

League of Nations. 1942. Commercial Policy in the Interwar Period: International Proposals and National Policies. Geneva: League of Nations.

Lopez-Cordova, J. Ernesto, and Christopher M. Meissner. 2003. "Exchange-Rate Regimes and International Trade: Evidence from the Classical Gold Standard Era.” American Economic Review 93, 344-353.

McDonald, Judith, Anthony Patrick O’Brien, and Colleen Callahan. 1997. “Trade Wars:

Canada’s Reaction to the Smoot-Hawley Tariff.” Journal of Economic History 57, 802-826.

Maddison, Angus. 2007. The World Economy. Paris: OECD.

Madsen, Jakob B. 2001. "Trade Barriers and the Collapse of World Trade during the Great Depression.” Southern Economic Journal 67, 848-868.

Meade, James E. 1955. “The Case for Variable Exchange Rates.” Three Banks Review 27: 327.

Mitchell, Brian R. 2007. International Historical Statistics: Africa, Asia, \& Oceania, 17502005. New York: Palgrave Macmillan.

Mitchell, Brian R. 2007. International Historical Statistics: Europe, 1750-2005. New York: Palgrave Macmillan.

Mitchell, Brian R. 2007. International Historical Statistics: The Americas, 1750-2005. New York: Palgrave Macmillan.

Moggridge, Donald. 1992. Maynard Keynes: An Economist’s Biography. New York: Routledge.

Myers, Margaret. 1936. Paris as a Financial Center. London: P.S. King.

Obstfeld, Maurice, and Alan M. Taylor. 1998. “The Great Depression as a Watershed: International Capital Mobility over the Long Run.” In Michael Bordo, Claudia Goldin, and Eugene White (eds.), The Defining Moment: The Great Depression and the American Economy in the Twentieth Century. Chicago: University of Chicago Press. 
$-38-$

Obstfeld, Maurice, Jay C. Shambaugh, and Alan M. Taylor. 2004. "Monetary Sovereignty, Exchange Rates, and Capital Controls: The Trilemma in the Interwar Period.” IMF Staff Papers 51, 75-108.

Palyi, Melchior. 1970. The Twilight of Gold. Chicago: Henry Regnery.

Peden, George. 2000. The Treasury View and British Public Policy 1906-1959. Oxford: Oxford University Press.

Ritschl, Albrecht, and Nikolaus Wolf. 2003. "Endogeneity of Currency Areas and Trade Blocs: Evidence from the Interwar Period.”

Rodríguez, Francisco, and Dani Rodrik. 2001. “Trade Policy and Economic Growth: A Skeptic’s Guide to the Cross-National Evidence.” In NBER Macroeconomics Annual 2000, edited by Ben Bernanke and Kenneth S. Rogoff. Cambridge: MIT Press.

Salmon, Patrick. 2003. "Paternalism or Partnership? Finance and Trade in Anglo-Danish Relations in the 1930s." In Britain and Denmark: Political, Economic and Cultural Relations in the 19th and 20th Centuries, edited by Jorgen Sevaldsen. Copenhagen: Museum Tusculanum Press.

Shearer, Ronald A. and Carolyn Clark. 1984. "Canada and the Interwar Gold Standard: Monetary Policy without a Central Bank.” In Michael D. Bordo and Anna J. Schwartz (eds.), $\underline{A}$ Retrospective on the Classical Gold Standard. Chicago: University of Chicago Press.

Simmons, Beth. 1994. Who Adjusts? Domestic Sources of Foreign Economic Policy During the Interwar Years, 1923-1939. Princeton: Princeton University Press.

Straumann, Tobias. 2009. "Rule Rather than Exception: Brüning’s Fear of Devaluation in Comparative Perspective.” Journal of Contemporary History 44, 603-617.

Temin, Peter. 1989. Lessons from the Great Depression. Cambridge: MIT Press.

Temin, Peter. 2008. “The German Crisis of 1931: Evidence and Tradition.” Cliometrica 2: 5-17.

Thomsen, Birgit Nuchel and Brinley Thomas. 1966. Danks-Engelsk Samhandel et Historisk Rids 1661-1963 (Anglo-Danish Trade 1661-1963: A Historical Survey). Aarhus: University Press of Aarhus.

Wandschneider, Kirsten. 2008. "The Stability of the Interwar Gold Standard: Did Politics Matter?” Journal of Economic History 68, 151-181.

Wei, Shang-Jin, and Zeiwei Zhang. 2007. “Collateral Damage: Exchange Controls and International Trade.” Journal of International Money and Finance 26, 841-863. 
Whittlesey, C. R. 1937. “Import Quotas in the United States.” Quarterly Journal of Economics, 52, 37-65.

Williamson, Philip. 1992. National Crisis and National Government: British Politics, the Economy and Empire, 1926-1932. Cambridge: Cambridge University Press.

Wolf, Holger C., and Tarik M. Yousef. 2007. "Breaking the Fetters: Why did Countries Exit the Interwar Gold Standard?” In The New Comparative Economic History: Essays in Honor of Jeffrey G. Williamson, edited by Timothy J. Hatton, Kevin H. O'Rourke, and Alan M. Taylor. Cambridge: MIT Press.

Wolf, Nikolaus. 2008. "Scylla and Charybdis. Explaining Europe’s Exit from Gold, January 1928-December 1936.” Explorations in Economic History 45, 383-401. 
Table 1: Exchange Rate and Payments Regimes, Sample Countries, 1929-1936

\begin{tabular}{|l|l|l|l|l|}
\hline & $\begin{array}{l}\text { Sterling bloc } \\
\text { countries }\end{array}$ & $\begin{array}{l}\text { Gold bloc } \\
\text { countries }\end{array}$ & $\begin{array}{l}\text { Exchange } \\
\text { Controls }\end{array}$ & $\begin{array}{l}\text { Others with } \\
\text { Depreciated } \\
\text { Currencies }\end{array}$ \\
\hline 1929 & $\begin{array}{l}\text { Argentina, } \\
\text { Australia }\end{array}$ & $\begin{array}{l}\text { Canada, Brazil, } \\
\text { Spain, Uruguay }\end{array}$ \\
\hline 1930 & New Zealand & $\begin{array}{l}\text { Fenmark, Egypt, } \\
\text { Japan, India, } \\
\text { Kweden, United } \\
\text { Thailand }\end{array}$ & $\begin{array}{l}\text { Austria, Bulgaria, } \\
\text { Czechoslovakia, } \\
\text { Denmark, } \\
\text { Germany, } \\
\text { Hungary }\end{array}$ & Colombia, Mexico \\
\hline 1932 & \begin{tabular}{l} 
Pertugal, Turkey \\
\hline 1933
\end{tabular} & South Africa & Romania & Chile, Greece \\
\hline 1934 & Switzerland & Belgium & Poland & Cuba, United States, \\
\hline 1935 & 1936 & Philippines \\
\hline
\end{tabular}

Note: Year of departure from the gold standard for columns 1, 2, and 4. Year of imposition of exchange controls for column 3.

Source: League of Nations, Money and Banking 1937/38, Vol. 1: Monetary Review, Geneva, 1939, pp. 107-109, and League of Nations, Report on Exchange Controls, Geneva, p. 29. These sources classify the gold bloc as Belgium, France, the Netherlands, and Switzerland, and classify the exchange control group as Austria, Bulgaria, Czechoslovakia, Denmark, Germany, Greece, Hungary, Italy, Poland, Portugal, Romania, Turkey, and Yugoslavia. Some of these latter countries also went off the gold standard at some point. Some countries that were part of the sterling bloc had departed from the gold standard before Britain (Argentina, New Zealand, Australia) and some after Britain (Thailand, South Africa). Denmark is a special case in that it was part of the sterling bloc but imposed exchange controls; see the text. Canada was not commonly classified as part of the sterling bloc; it was on the gold standard for a short time (1926-29) but maintained a managed float between sterling and the dollar; see Shearer and Clark (1984) and Bordo and Redish (1990). 
Table 2: Relationship between Change in Average Tariff and Exchange Rate, 1928-1935

Dependent Variable: $\Delta \log (1+\tau)_{\text {it }}$

\begin{tabular}{|c|c|c|c|c|c|c|}
\hline & \multicolumn{3}{|c|}{ OLS } & \multicolumn{3}{|c|}{ IV } \\
\hline & (1) & $(2)$ & (3) & (1) & (2) & (3) \\
\hline $\begin{array}{l}\text { Exchange Rate } \\
\text { (Ratio of Gold } \\
\text { Par) }\end{array}$ & $\begin{array}{l}0.09 * \\
(0.05)\end{array}$ & $\begin{array}{l}0.10^{*} \\
(0.05)\end{array}$ & $\begin{array}{l}0.18^{*} \\
(0.08)\end{array}$ & $\begin{array}{l}0.21^{*} \\
(0.10)\end{array}$ & $\begin{array}{l}0.13^{*} \\
(0.07)\end{array}$ & $\begin{array}{l}0.35 * \\
(0.18)\end{array}$ \\
\hline $\begin{array}{l}\text { Exchange Control } \\
\text { indicator }\end{array}$ & -- & $\begin{array}{l}-0.01 \\
(0.03)\end{array}$ & $\begin{array}{l}-0.01 \\
(0.02)\end{array}$ & -- & $\begin{array}{l}-0.06 \\
(0.03)\end{array}$ & $\begin{array}{l}-0.09 * \\
(0.05)\end{array}$ \\
\hline $\begin{array}{l}\text { Log of Wholesale } \\
\text { Prices }\end{array}$ & -- & -- & $\begin{array}{c}0.10 \\
(0.08)\end{array}$ & -- & & $\begin{array}{l}0.27 * \\
(0.14)\end{array}$ \\
\hline $\mathrm{N}$ & 40 & 40 & 35 & 40 & 29 & 29 \\
\hline $\mathrm{F}$ & 3.5 & 2.3 & 3.3 & - & -- & -- \\
\hline $\mathrm{R}^{2}$ & 0.11 & 0.12 & 0.13 & -- & -- & -- \\
\hline First-stage F & -- & -- & -- & 4.6 & $24.4,49.8$ & $27.1,39.6$ \\
\hline
\end{tabular}

Note: Robust standard errors are reported. Constant term not reported. * = significance at 10 percent level. Instrument in column (1) is an indicator for financial center country. Instruments for columns (2) and (3) are financial center indicator and log of price level in 1923. 
Table 3: Trade Costs, selected countries (ad valorem equivalent)

Note: See text regarding calculation.

A. Britain

\begin{tabular}{|l|c|c|}
\hline & 1928 & $\begin{array}{c}\text { Percentage Change } \\
\text { 1928-1935 }\end{array}$ \\
\hline Overall & 0.49 & 7.7 \\
\hline Sterling bloc & 0.47 & 7.9 \\
\hline Gold bloc & 0.45 & 9.0 \\
\hline $\begin{array}{l}\text { Exchange } \\
\text { Control group }\end{array}$ & 0.52 & 7.0 \\
\hline United States & 0.42 & 10.8 \\
\hline
\end{tabular}

B. France

\begin{tabular}{|l|c|c|}
\hline & 1928 & $\begin{array}{c}\text { Percentage Change } \\
\text { 1928-1935 }\end{array}$ \\
\hline Overall & 0.56 & 9.8 \\
\hline Sterling bloc & 0.58 & 9.1 \\
\hline Gold bloc & 0.46 & 13.0 \\
\hline $\begin{array}{l}\text { Exchange } \\
\text { Control group }\end{array}$ & 0.57 & 10.3 \\
\hline United States & 0.50 & 14.3 \\
\hline
\end{tabular}

C. Germany

\begin{tabular}{|l|c|c|}
\hline & 1928 & $\begin{array}{c}\text { Percentage Change } \\
1928-1935\end{array}$ \\
\hline Overall & 0.50 & 11.9 \\
\hline
\end{tabular}


$-43-$

\begin{tabular}{|l|c|c|}
\hline Sterling bloc & 0.50 & 14.0 \\
\hline Gold bloc & 0.42 & 21.2 \\
\hline $\begin{array}{l}\text { Exchange } \\
\text { Control group }\end{array}$ & 0.49 & 8.7 \\
\hline United States & 0.47 & 23.7 \\
\hline
\end{tabular}

D. Sweden

\begin{tabular}{|l|c|c|}
\hline & 1928 & $\begin{array}{c}\text { Percentage Change } \\
\text { 1928-1935 }\end{array}$ \\
\hline Overall & 0.68 & 7.2 \\
\hline Sterling bloc & 0.60 & 15.6 \\
\hline Gold bloc & 0.52 & 21.9 \\
\hline $\begin{array}{l}\text { Exchange } \\
\text { Control group }\end{array}$ & 0.70 & 10.7 \\
\hline United States & 0.50 & 23.9 \\
\hline
\end{tabular}

Note: Sterling bloc includes Britain, Finland, Sweden, Norway, Portugal, India, Japan, Canada, New Zealand, and Australia. Gold bloc includes Belgium, France, the Netherlands, Switzerland, and Poland. Exchange control group includes Germany, Hungary, Chile, Roumania, Bulgaria, Denmark, Italy, and Austria. 
Figure 1: Measures of World Trade and Production, 1924-1938

Source: League of Nations (1939c), Appendix III, and Maddison (2006).

A. Volume of World Trade and World GDP

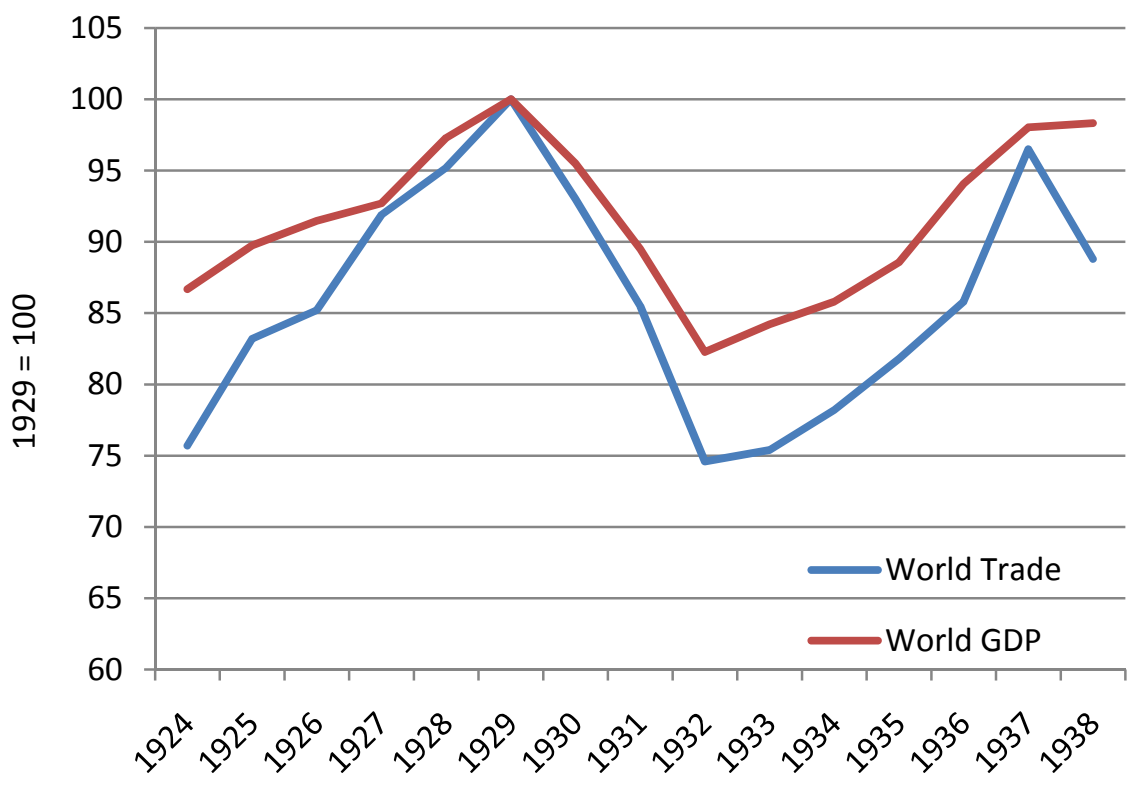

B. Manufactured Goods: Volume of World Trade and Production

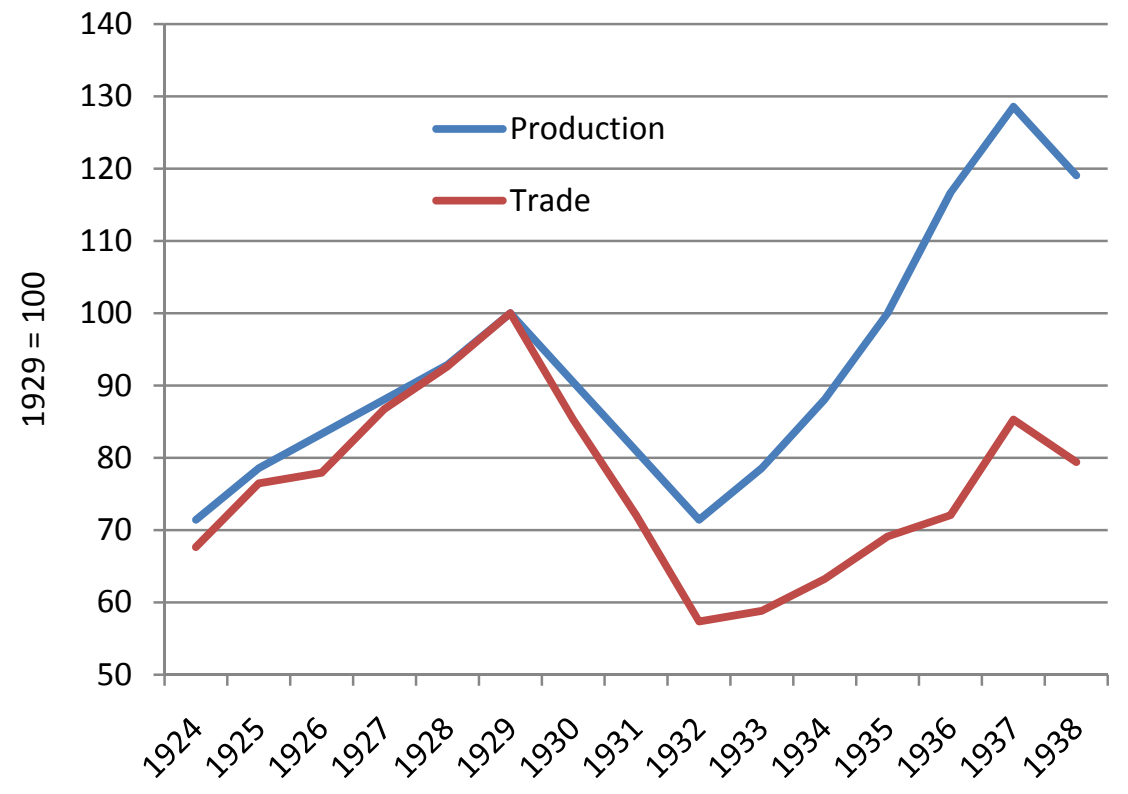


Figure 2: Average Percentage Tariff Rate on Imports, various countries, 1928, 1935, 1938 Source: see text.

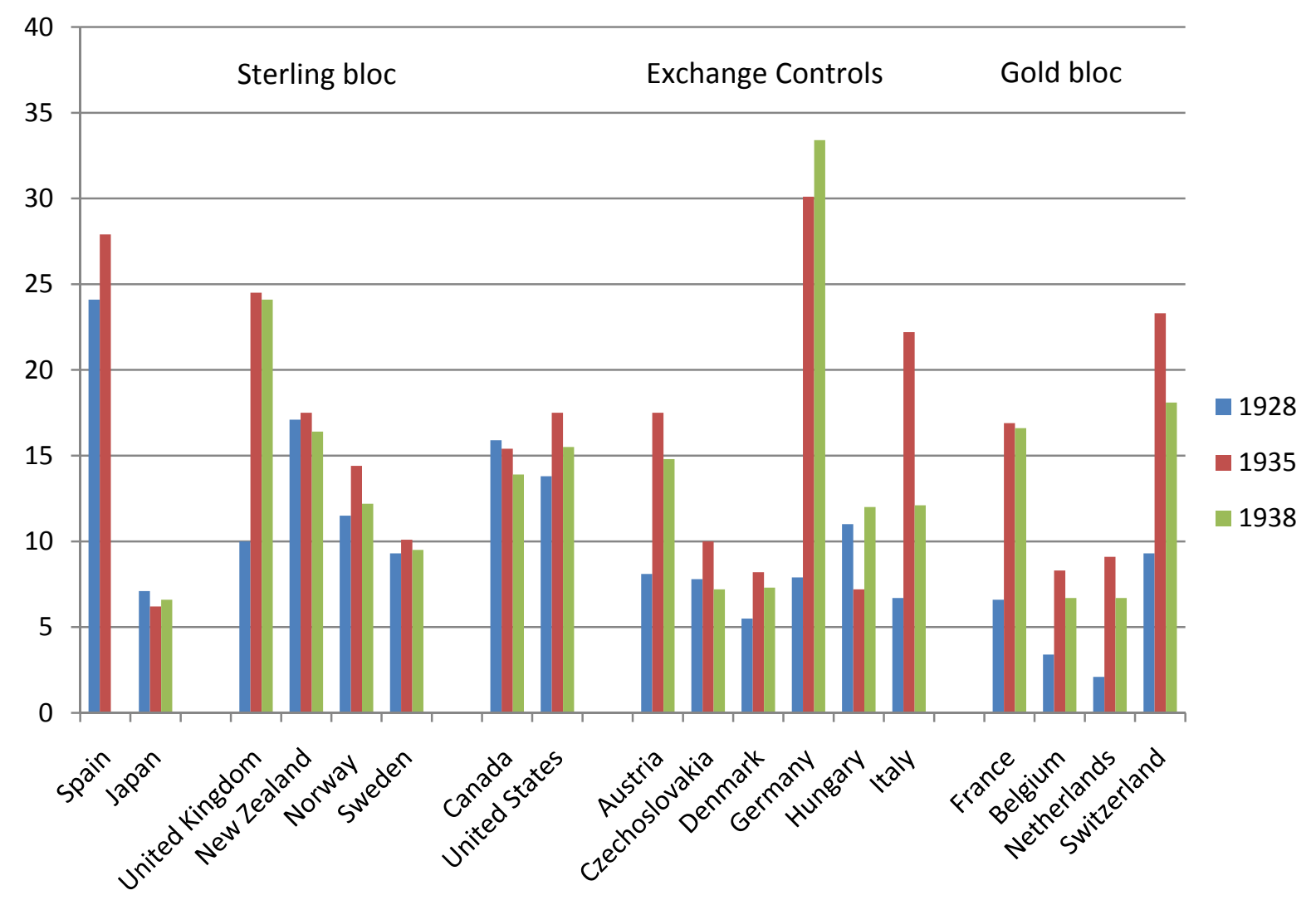


-46-

Figure 3: Exchange Rate and Change in Import Tariffs, 1929 - 1935
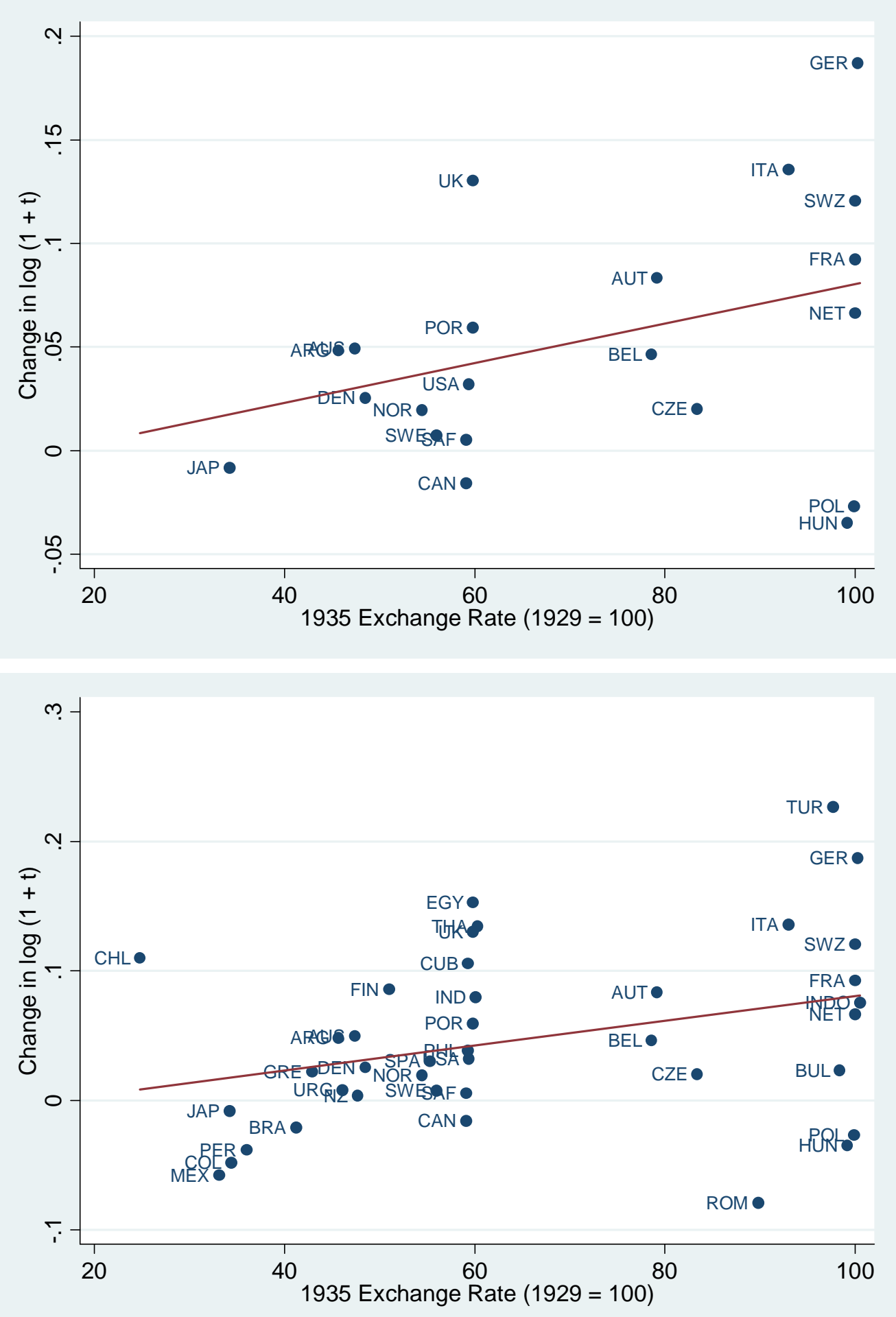
Figure 4: Exchange Rate Change and Use of Import Quotas

Note: Share of imports covered by import quotas.

Source: League of Nations (1939b, 189), Whittlesey (1937).

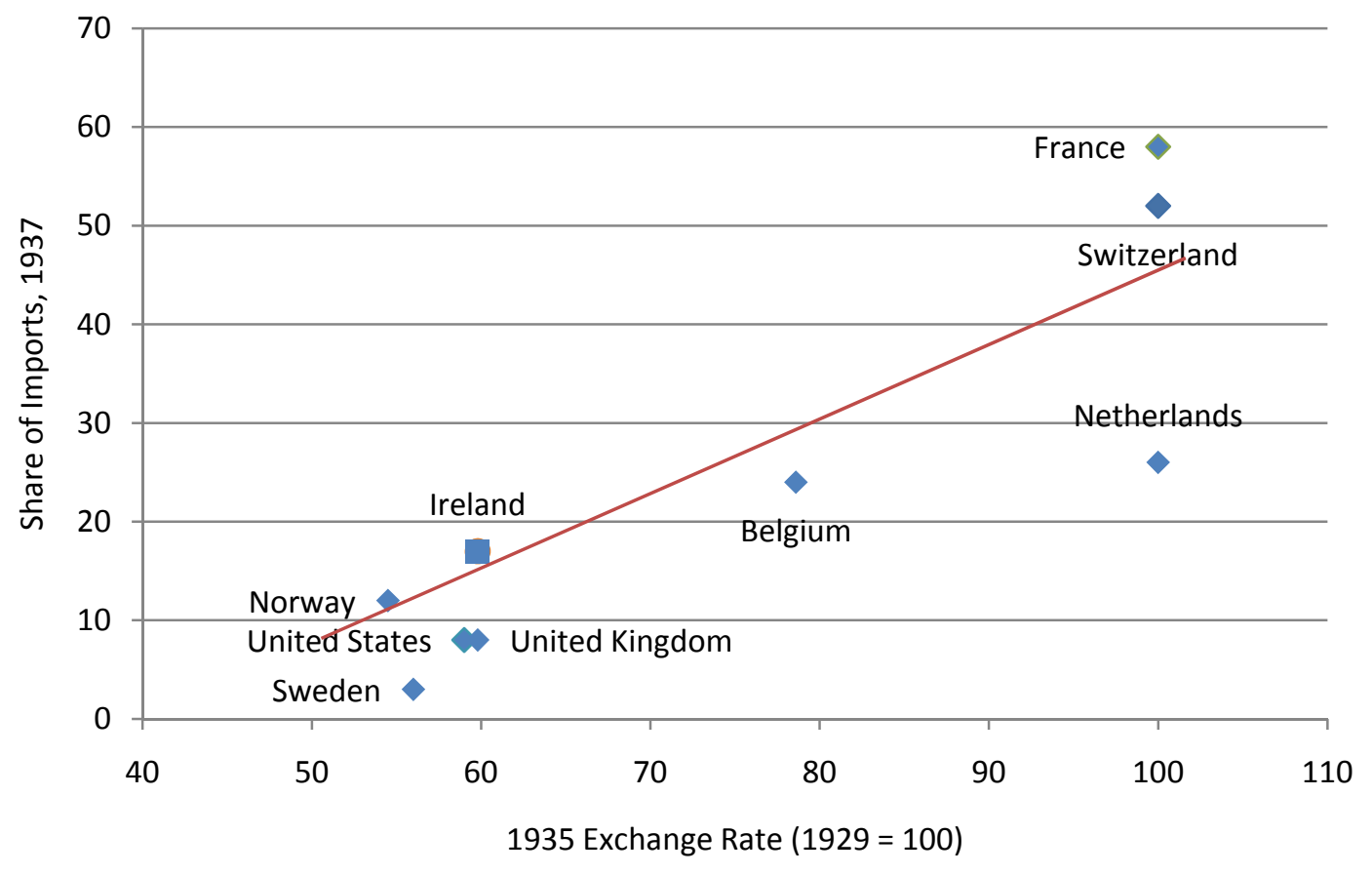


$-48-$

Figure 5: Percentage Change in Import Volume, 1928-1935

Source: League of Nations (1939a), Annex II.

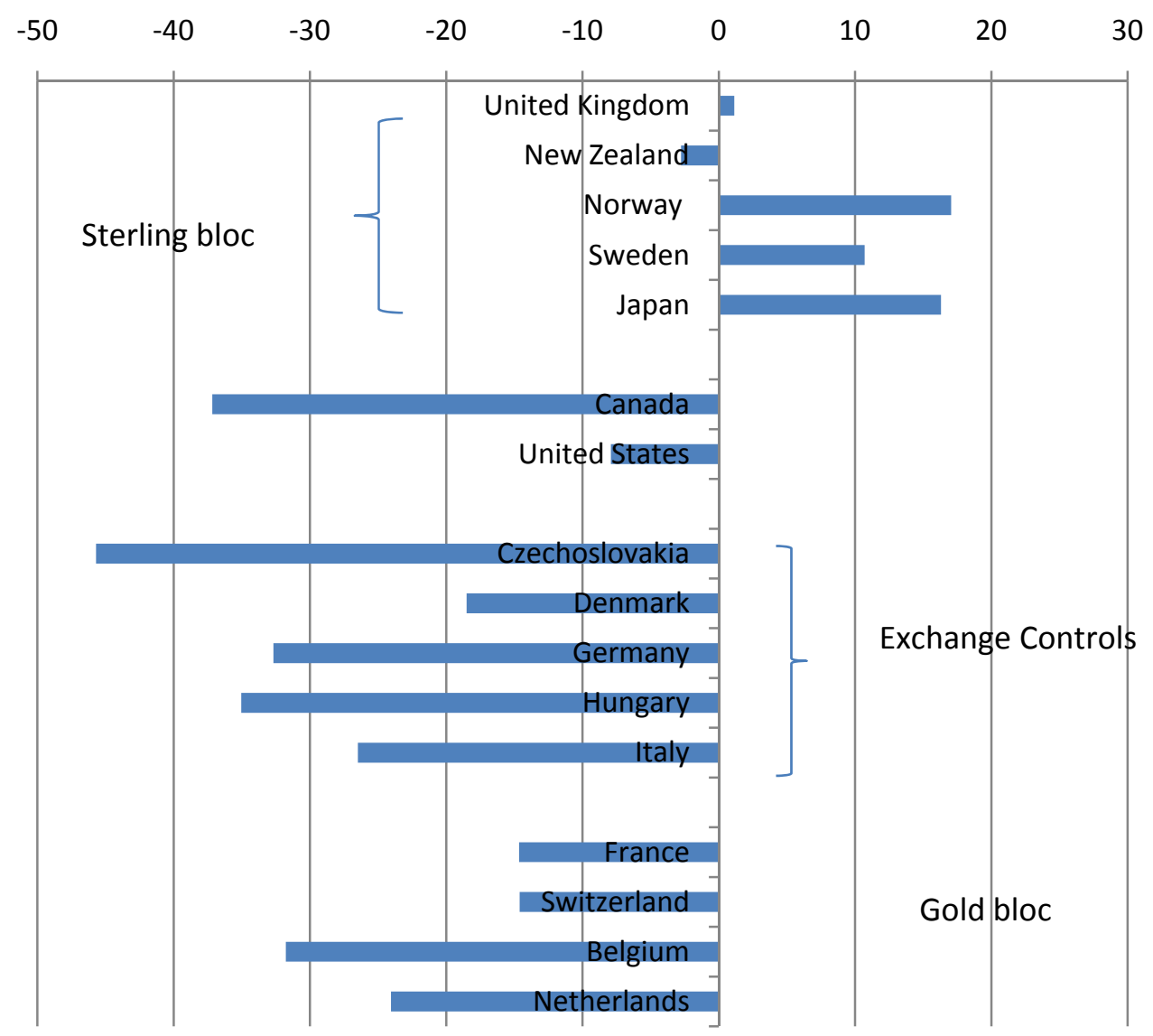


-49-

Figure 6: Change in Import Volume and Real GDP, 1929-1935

Note: Regression line excludes exchange control countries (denoted by red border).

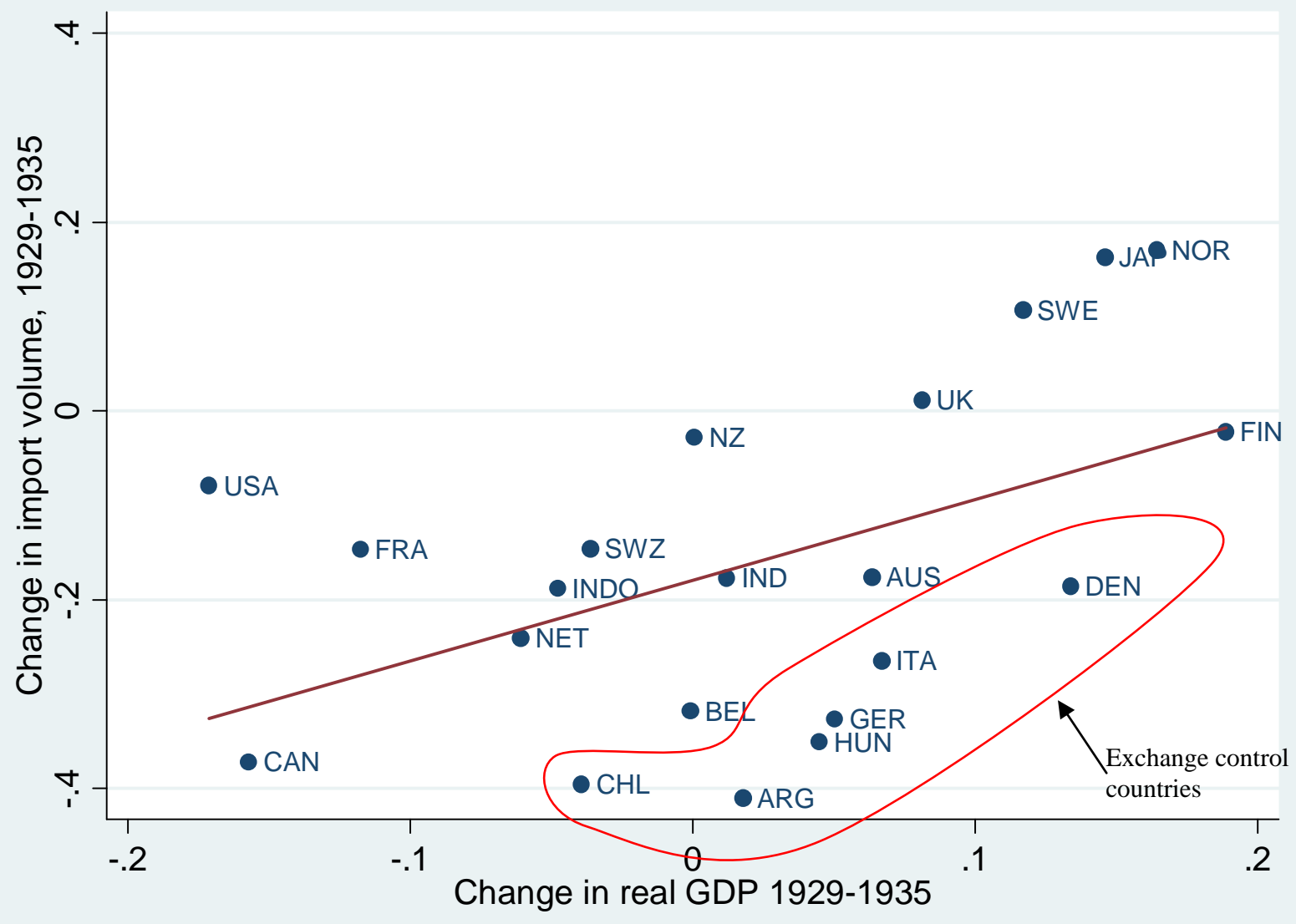


$-50-$

Figure 7: Change in Trade Costs and Exchange Rate

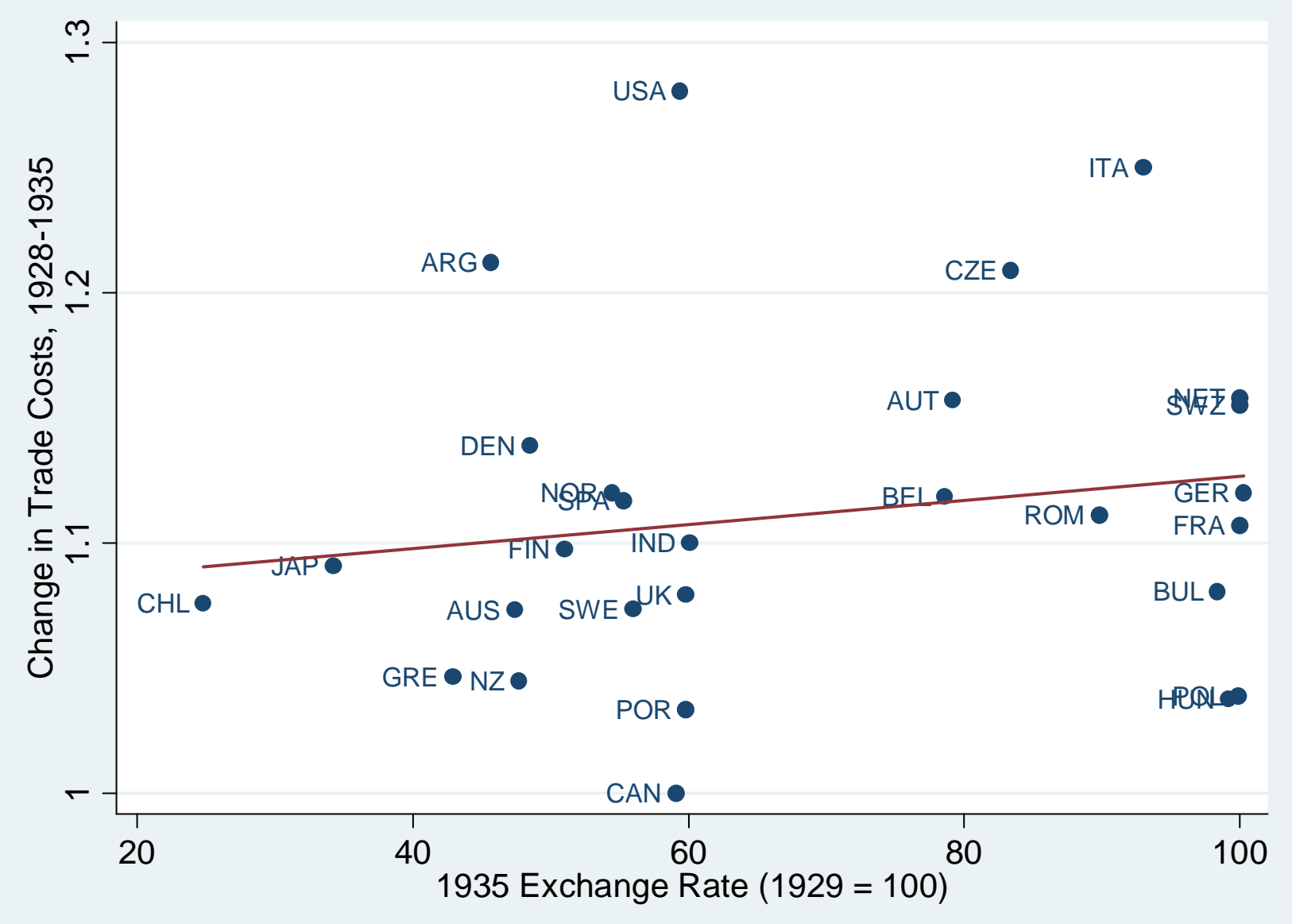

